\title{
KARST EVOLUTION OF THE GARRAF MASSIF (BARCELONA, SPAIN): DOLINE FORMATION, CHRONOLOGY AND ARCHAEO- PALAEONTOLOGICAL ARCHIVES
}

\author{
Joan Daura', Montserrat Sanz', Joan Josep Fornós², Antoni Asensio³, and Ramon Julià
}

\begin{abstract}
Karst landscape evolution has been widely studied in recent years on karst plateaus, but the use of dating methods has not usually been possible owing to a lack of data. The intensely karstified Garraf Massif, however, presents large solution dolines and several shafts that contain archaeological and palaentological remains that can be used for determining the chronological framework of the karstification processes. These sites have been dated using various techniques, and the resulting data combined with evidence from previous geomorphological studies. The results allow us to define the pattern and timing of the evolution of karst morphologies in the northeast of the Iberian Peninsula. We propose a simple five-stage geomorphological model of the evolution of the Garraf dolines located on the plateau, between the Middle to Upper Miocene and the Holocene. The study also provides important information for analyzing landscape history in high plateaus of karst regions.
\end{abstract}

\section{INTRODUCTION}

Various models of the geomorphological formation and evolution of dolines have been proposed, based on the study of sedimentary fills (Sauro et al., 2009), host-rock dissolution processes (Zambo and Ford, 1997), and deposit morphology and architecture (Ford and Williams, 2007; Waltham et al., 2005). Solution dolines are the most commonly studied of the karst landforms, having been described in detail since the end of the nineteenth century (Cvijic, 1893), while collapse sinkholes are perhaps the most spectacular, with the tiankengs in the karst areas of China providing the best examples ( $\mathrm{Zhu}$ and Waltham, 2005). Recently, many studies conducted in different karst regions have proposed new models for the full evolutionary sequence of doline development (Gibbard et al., 1986; Bruxelles et al., 2008, 2012; Luzón et al., 2008; Siart et al., 2010).

Chronological approaches to the dating of doline and karst evolution are limited and involve associating these depressions with the archaeological or palaeontological record (Ufrecht, 2008). Sediment-filled depressions, mainly dolines, have been used as promising records for geoarchaeological research (Van Andel, 1998; Bruxelles et al., 2006), especially as part of a multidisciplinary approach (Siart et al., 2010), and have led to a better understanding of the chronological framework. Such studies provide absolute ages of the sediments and the materials preserved in the dolines, which makes it possible to date the doline formation. This has been the case, for example, of the Doline d'Orgnac 3 (Moncel, 2003; Moncel et al., 2005), the doline of Cantalouette (Bourguignon, 2004), the dolines in the Causses region (Quilès et al., 2002), and the doline in Visogliano (Falguères et al., 2008), among others.
More common is the use of these sediment-filled depressions for archaeological and palaeoenvironmental reconstruction (Gibbard et al., 1986, Bruxelles et al., 2008; Siart et al., 2010; Bruxelles et al., 2012). Most of these reconstructions have been conducted in ancient Mediterranean landscapes (Marriner and Morhange, 2007; Fouache et al., 2008), where the abundance of karst regions without running surface water and any associated sediment accumulations has hindered reconstruction owing to the absence of corresponding non-karst archives. These studies emphasize the importance of karst depressions as highly valuable, unique sources of information. These depressions act as traps for eroded soils that may accumulate and be preserved from further erosion, thereby facilitating the analysis of landscape evolution, chronology, and associated palaeoenvironmental phases (Hempel, 1991).

More than three hundred shafts are documented in the central Garraf Massif, and studies of this karst region have a long geological and speleological tradition dating back to the end of the nineteenth century (Font, 1897). Work carried out during the 1940s and 1950s offered an initial model of the Garraf karst's origin and development, providing an initial chronological approach to understanding doline formation (Llopis, 1943, 1947; Montoriol, 1950,

\footnotetext{
${ }^{1}$ G.R.Q. Grup de Recerca del Quaternari. SERP. Dept. Prehistòria, H. Antiga i Arqueologia. Facultat de Geografia i Història. Universitat de Barcelona. C/ Montalegre, 6. 08001, Barcelona, Spain.grq@ub.edu

${ }^{2}$ Departament de Ciències de la Terra, Universitat de les Illes Balears. Ctra. Valldemossa km 7, 5. 07122 Illes Balears, Spain

${ }^{3}$ S.E.O. del C.E.V. Secció Espeleològica de l'Ordal del Centre Excursionista de Vallirana. C/Major, 402. 08759. Vallirana, Barcelona, Spain

${ }^{4}$ Institut Ciències de la Terra "Jaume Almera". CSIC. C/Lluís Solé Sabarís s/n. 08028, Barcelona, Spain
} 
Karst evolution of the Garraf Massif (Barcelona, Spain): doline formation, Chronology and archaeo-Palaeontological ARCHIVES

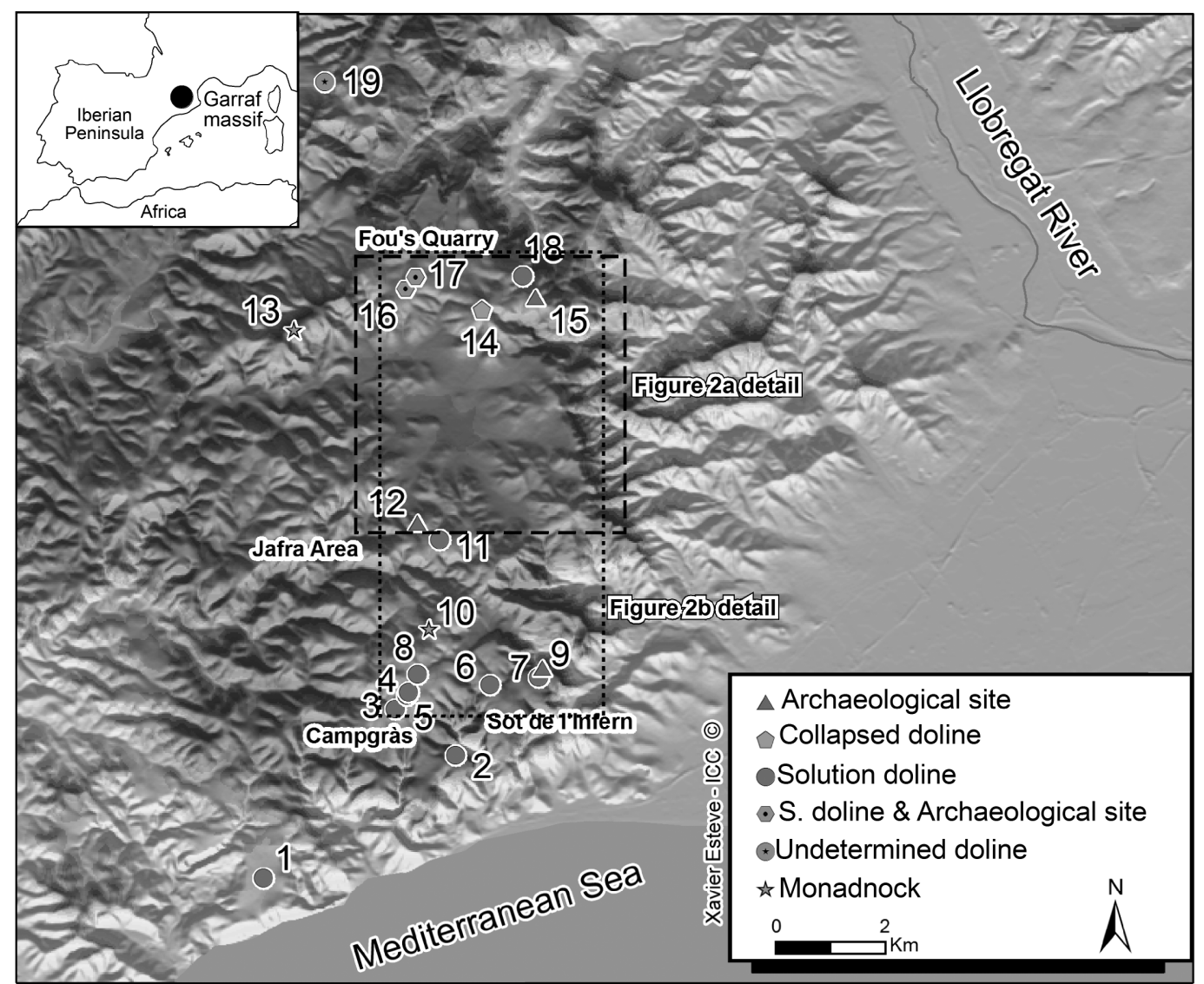

1: Campdàsens. 2: Pic Martell. 3: Pla de Querol. 4: Campgràs-C. 5: Campgràs-B. 6: Bassot de l'Arbre. 7: Puig de l'Olla. 8: Campgràs-A. 9: Site 4-Cova Bonica . 10: Morella. 11: Serra de la Guàrdia. 12: Coll Sostrell. 13: Montau. 14: Sotarro. 15: Site 3-Avenc Marcel. 16: Site 1-Esquerda de les Alzines. 17: Site 2-Alzines. 18: Serra del Mas. 19: Coll de l'Ordal.

Figure 1. Location of the study area and of the principal dolines and their associated deposits (Source: X. Esteve and ICC, Institut Cartogràfic de Catalunya).

1954; Montoriol and Muntan, 1959, 1961), while more recent studies have focused their attention on other karst features (Freixes, 1989; Custodio et al., 1993). However, the somewhat simplistic and schematic studies undertaken during the 1950s do not provide any direct dating of the region's doline formation. More recently, the Grup de Recerca del Quaternari of the University of Barcelona (GRQ-UB) has initiated sedimentological and archaeological work aimed at obtaining more precise dates for the Pleistocene sedimentary fills in the Garraf karst (Daura, 2008).

The findings from these earlier studies, combined with more recent geomorphological and chronological data, allow us to initiate development of a chronological model that can be extrapolated to other karst massifs in the Iberian Peninsula and the Western Mediterranean and to establish the chronology of doline sedimentation stages. Furthermore, we present the karst cavities of the Garraf Massif as a specific case study that can be used to explain the apparent hiatus in Pliocene and Pleistocene sedimentary fill on karst plateaus.

\section{Geological Setting and Study Area}

\section{GARRAF MASSIF}

Occupying an area of around $500 \mathrm{~km}^{2}$ (Salas, 1987), the Garraf Massif is a horst located in the northeast of the Iberian Peninsula, $30 \mathrm{~km}$ southwest of the city of Barcelona. The massif, composed mainly of Jurassic and Cretaceous limestone and dolostone (Figs. 1 and 2), is a low-relief mountain range that rises to a height of less than $600 \mathrm{~m}$ as a result of gentle tilting. On the eastern side of the massif, Palaeozoic (Benet, 1990) and Triassic materials can be found (Marzo, 1979).

Cretaceous carbonate rocks (Andreu et al., 1987; Salas, 1987; Albich et al., 2006; Moreno, 2007) dominate the central part of the massif, where most of the karst landforms have developed (Borràs, 1974; Lloret, 1979; Rubinat, 1981; Asensio, 1993; Rubinat, 2004). The Cretaceous formations consist of limestone with dolomitic intercalations from the Valanginian and Barremian stages. Outcrops of Cretaceous marls and marly limestone (Salas, 1987) of Aptian age (Moreno, 2007) are also found in a few areas. 


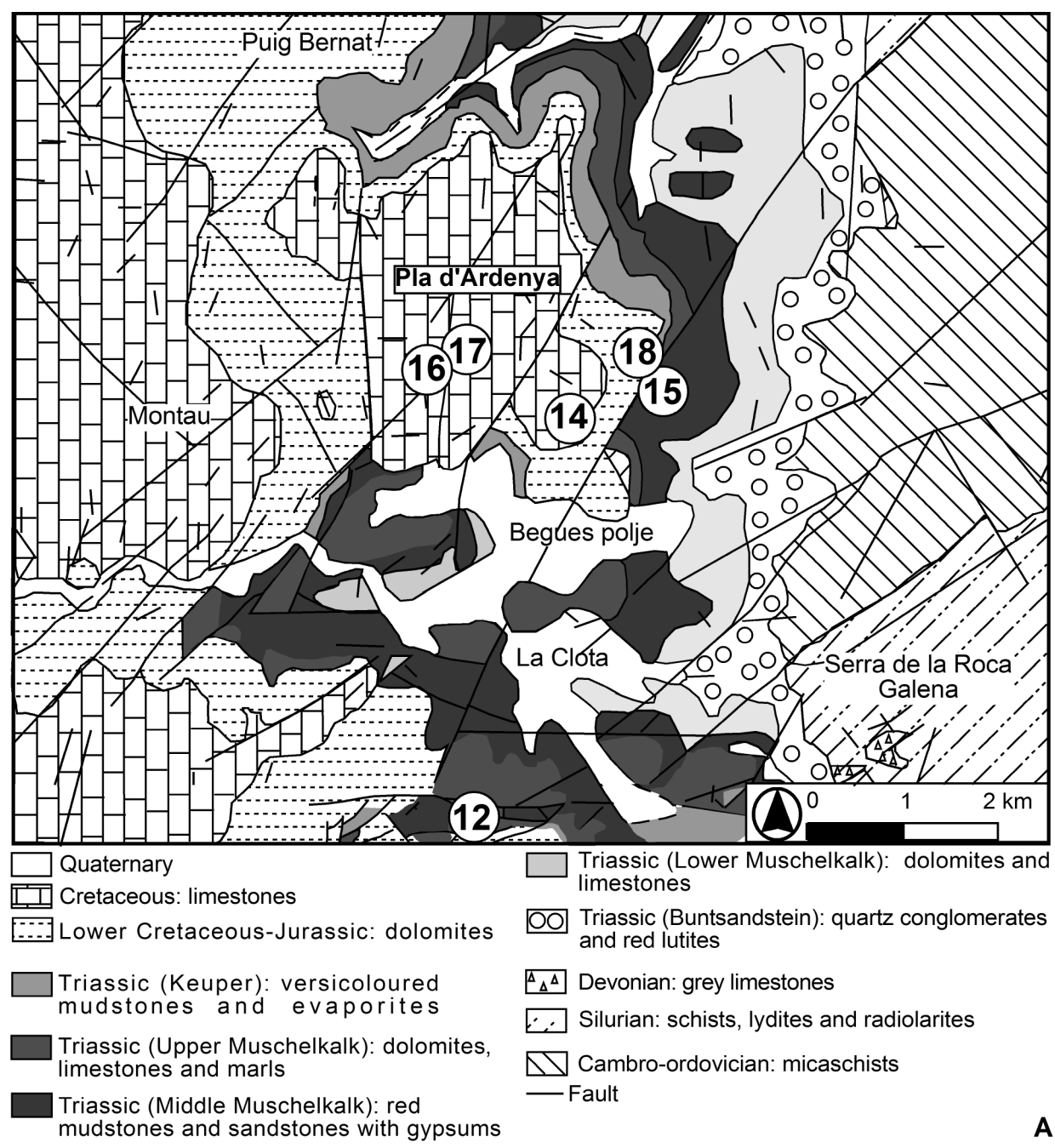

3: Pla de Querol. 4: Campgràs-C. 5: Campgràs-B. 6: Bassot de l'Arbre. 7: Puig de I'Olla. 8: Campgràs-A. 9: Site 4-Cova Bonica .12: Coll Sostrell. 14: Sotarro. 15: Site 3-Avenc Marcel. 16: Site 1-Esquerda de les Alzines. 17: Site 2-Alzines. 18: Serra del

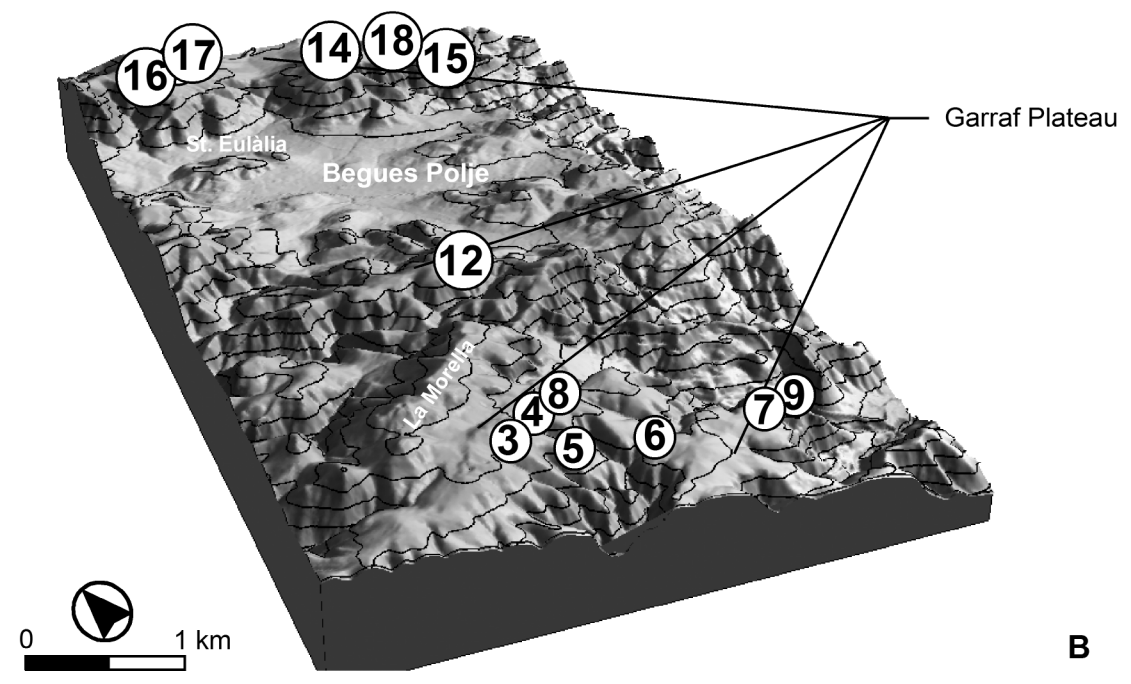

Figure 2. A: Geologic map of the central part of the Garraf Massif with the location of its main dolines and their associated deposits. B: Digital elevation model of the Garraf plateau showing the location of main dolines and shafts. 
Karst evolution of the Garraf Massif (Barcelona, Spain): doline formation, Chronology and archaeo-Palaeontological ARCHIVES

Garraf karstification is concentrated in the massif's fractured carbonate rocks, and its main karst features include dolines, shafts, and caves containing Pleistocene sedimematry fill (Daura et al., 2005, 2010a,b). Structurally, the limestone massif is an antiform (Bartrina et al., 1992), resulting from a northeast to southwest compression of the alpine orogeny, and a series of fractures trending predominantly northeast to southwest run across the entire complex (Guimerà, 1988). Fractures control almost all the development of shafts in the massif, including those beneath the doline perimeters.

\section{Garraf Dolines and Plateau}

Generally, the Garraf dolines are found in Cretaceous rocks. The Jurassic strata in the high plains present less significant karst development and fewer dolines. The Triassic carbonates comprise strata that only crop out in the northeast of the Garraf Massif rim. On the Garraf plateau, several areas (Llopis, 1941) of doline density can be discerned (Fig. 1). The most significant accumulation lies between Campgràs, Puig de l'Olla, and Sot de l'Infern, with a total of thirteen dolines, followed by Coll de l'OrdalLledoner, with twelve depressions, and Pla d'Ardenya with four preserved dolines (Fig. 2).

According to the models proposed by Waltham et al. (2005, p. 26 and subseq.) and Ford and Williams (2007, p. 339 and subseq.), these dolines can be classified into two main types. The first includes dolines with higher concavity indices, with no or very scarce sedimentary deposits, and with well-developed shafts in the center. These dolines, for example, the Dolina del Sotarro or the dolines in southeast Campgràs, have previously been described by Montoriol (1950, 1954) and Montoriol and Muntan (1958, 1959) and will not be dealt with here.

The second type includes dolines with low concavity indices and depressions that are associated with undeveloped shafts. These dolines usually present large sedimentary terra-rossa type deposits produced by chemical weathering within their perimeters. Most dolines in the Garraf Massif are of this type, and examples include the dolines in les Alzines, Esquerda de les Alzines, Campgràs, Pla de Querol, Bassot de l'Arbre, Puig de l'Olla, and Serra del Mas among others (Fig. 1).

The dolines of low concavity and their associated shafts in the Garraf plateau present the best morphologies for studying karst-landscape evolution thanks to their sedimentary fill. This plateau (Fig. 2-B) is an erosional surface that, following an episode of uplift during the late Miocene, now lies between 450 and $550 \mathrm{~m}$ amsl, as determined by Llopis (1947), and corresponds to a period during the Miocene when the sea level (base level here) was probably stable for a long period. Correlation between the erosional surface of the limestone massif and sea levels have been based on marine deposits (Llopis, 1947) located on the northwest side of the massif. These deposits correspond to the Middle to Upper Miocene (Machpher- son, 1994; de Porta and Civis, 1996). During that time most of the littoral range would have been submerged (Gallart, 1980), and while the emerging part of the Garraf Massif was developing an erosional surface, the sunken part of the depression preserved its pre-flooding relief intact, due to its own fossilization. Some of the highest peaks in the massif today are evidence of the aforementioned process of erosion and levelling. Examples such as Morella and Montau (Fig. 1) have been considered monadnocks, i.e., rocky masses that survived the erosion and stand isolated above the general level of the plateau. After Llopis (1947), subsequent authors have considered this karst plain to be a peneplain (Montoriol, 1954; Montoriol and Muntan, 1961).

Today the karst plain is no longer continuous, as faulting has separated it into different blocks. The main faults in the Garraf block are arranged in two orthogonal systems, one aligned with the Garraf Massif (NE-SW) and the other perpendicular to the range (NW-SE) (Fig. 2). Some minor faults also follow this pattern. This group of faults is responsible for the sinking of some blocks and the elevation of others. The most significant case is the Begues plain, where a polje subsequently evolved and divides the two main areas with a high concentration of dolines.

Shafts containing sedimentary fill and located under the Garraf plateau are especially relevant here because they preserve records that can be used to understand the evolution and chronology of the karst plain. These shafts have developed along vertical tectonic fractures, predominantly at the base of the epikarst zone. These shafts, coneor bell-shaped and blind, reach upwards to near the surface, but many of them have no natural opening to the surface, and those that do, often owe their development to surface activity (tree-root action, speleological works, subsoil corrosion, etc.). None of them has a known accessible connection to an active horizontal cave system.

This morphology, which is common in the Garraf Massif, suggests an upward shaft development formed by ascending erosion (Maucci, 1960; Jennings, 1985; Klimchouk, 2000; Baroň, 2002; Jones et al., 2004); however, neither hypogenetic processes nor up-welling deep waters have been recorded in the Garraf plateau.

\section{Site Description}

This study focuses on four sites in the Garraf plateau containing archaeological and palaeontological remains (Fig. 2). The first two sites, site 1, Esquerda de les Alzines and site 2, Alzines, were discovered in 2004 by two of the authors (JD and MS). They are solution dolines (dolina) excavated between 2004 and 2009 by the Grup de Recerca del Quaternari, and both contain shafts (avenc) below the depression. Besides these dolines, two additional karst formations on the Garraf karst plain, site 3, Avenc Marcel and site 4, the Cave (Cova) Bonica, were discovered during speleological work in the twentieth century and are of the 
utmost importance when establishing a chronological framework for the first Quaternary sediment deposition at this level of the general erosion surface.

\section{Site 1: Esquerda de les Alzines}

Site 1 is the Dolina de Esquerda de les Alzines (DEA) and its subterranean network of shafts (Fig. 3). It is a solution doline located at the convergence of two faults (d1 and d2) extending over approximately $2 \mathrm{~km}$. The doline is located at between 530 and $523.6 \mathrm{~m}$ amsl and is elliptical in shape. The depression is $40-\mathrm{m}$ long by $30-\mathrm{m}$ wide, with a maximum depth of $11 \mathrm{~m}$. Its central section has been significantly modified as a consequence of speleological work (GIRES, 1995) carried out during the 1990s.

The site, delimited by the doline perimeter, includes four shafts (Avenc de l'Esquerda de les Alzines, Avenc Gran de l'Esquerda de les Alzines, Avenc dels Arqueòlegs and Avenc Petit de l'Esquerda de les Alzines) that together form a subterranean network that has developed along faults $\mathrm{d} 1$ and $\mathrm{d} 2$.

Archaeological work undertaken in Layer $\mathrm{C}$ and in the mixed sediments of the DEA by the GRQ-UB recovered 1,067 artifacts (Fig. 4). They are characterized by a predominance of flakes from the reduction of cores and artifacts of various morphologies. However, the chronological framework and technological traits identified do not allow the site to be placed within a particular one of the Upper or Middle Palaeolithic tool groups, although the recovery of some artifacts commonly found in Upper Palaeolithic assemblages suggests a connection to this period (Daura et al., 2011).

\section{Site 2: Alzines}

Site 2, or Alzines, corresponds to a solution doline and its subterranean network of shafts. The doline, known as Dolina II de les Alzines (DA) (Fig. 3), is located $290 \mathrm{~m}$ to the northeast of Site 1. Located on the same plateau, between 528.2 and $523.6 \mathrm{~m}$ amsl, it is more elliptical in shape than DEA and has also developed on fault d1. Its present day surface has been modified by speleological work carried out in the 1960s by the Grup Exploracions Subterrànies (Montoriol, 1964) and by subsequent work by the Grup d'Investigacions, Recerques i Espeleologia Sesrovires and the Secció Espeleològica Ordal del Centre Excursionista de Vallirana.

Site 2, delimited by the perimeter of DA, contains a significant subterranean network, comprising two main shafts. The first of these, Avenc de les Desil-lusions, also named Avenc Nou de les Alzines (Valdepeñas, 2012), was discovered during GRQ-UB excavations (Daura and Sanz, 2010) and does not contain any Pleistocene remains. The second, Avenc de les Alzines, contains archaeological and palaeontological remains that appear to have entered the shaft from Parets dels Ossos (Table 1).

Large mammal bones have been recovered at the base of the DA in a mass of cemented red breccia. As the site's faunal remains are still being restored, palaeontological analyses are not yet available. Therefore Table 1 only provides a preliminary assignment of bear remains as Ursus sp. Collapsed sediments throughout Parets dels Ossos provide rhinoceros remains (Stephanorhinus etruscus) corresponding to posterior extremities, isolated hyena teeth and carpals, and a few stone tools (Daura 2008).

\section{Site 3: Avenc Marcel}

Located in the Triassic (Upper Muschelkalk) dolostone and limestone, Avenc Marcel (Fig. 5) is a complex system of $80 \mathrm{~m}$ deep, spindle-shaped shafts, developed as a result of rock fracturing and cliff regression. It was discovered in 1982 during the erection of a transmission tower and explored fully for the first time in 1989 by one of the authors (AA). Palaeontological remains were recovered at the original collapsed entrance during the first exploration (Asensio, 1993) (Table 1). In 2002, a palaeontological excavation by B. Martínez-Navarro, J. Agustí, and M. Llenas from the Institut Català de Paleontologia Miquel Crusafont was carried out in the shaft, but no archaeological or palaeontological remains were found (MartínezNavarro et al., 2002).

\section{Site 4: Cova Bonica}

Cova Bonica is a small cave chamber containing a vertical shaft near a significant fracture, which is also in contact with the Triassic dolostone and limestone. Sediments have been displaced through the vertical shaft and fissures from an area of the plateau with a high density of dolines. The cave was first explored during the nineteenth century (Font, 1899) and at various times in the twentieth (Montoriol, 1954; Borràs, 1974) by speleologists and geological groups. Studies have been conducted on the palaeontological remains (Table 1), focusing on small mammals (Agustí, 1988; Blain and Bailón, 2006; Blain, 2009) and primates (Delson, 1971, 1973, 1974; Delson and Nicolaescu-Plopsor, 1975; Crusafont-Pairó and Golpe-Posse, 1984).

\section{Methods}

To determine the chronology of doline formation and evolution, a series of field surveys were conducted at sites 1 , the dolina de Esquerda de les Alzines, and 2, the Dolina II de les Alzines. Several test pits were dug with a power shovel, reaching a maximum depth of $6 \mathrm{~m}$ below the current floor level to where the Mesozoic host rock cropped out. Sections from each test pit were stratigraphically described, and sediment samples were taken to study the fill.

The samples and cores were bagged, numbered, and taken to the Earth Sciences Department at the University of Illes Balears, where they were opened, sectioned lengthwise, photographed, and sampled at different intervals in stratigraphical order, according to the different layers observed. The presence of sedimentary structures, such as laminations, and other general observations were noted. 
Karst evolution of the Garraf Massif (Barcelona, Spain): doline formation, Chronology and archaeo-Palaeontological ARCHIVES

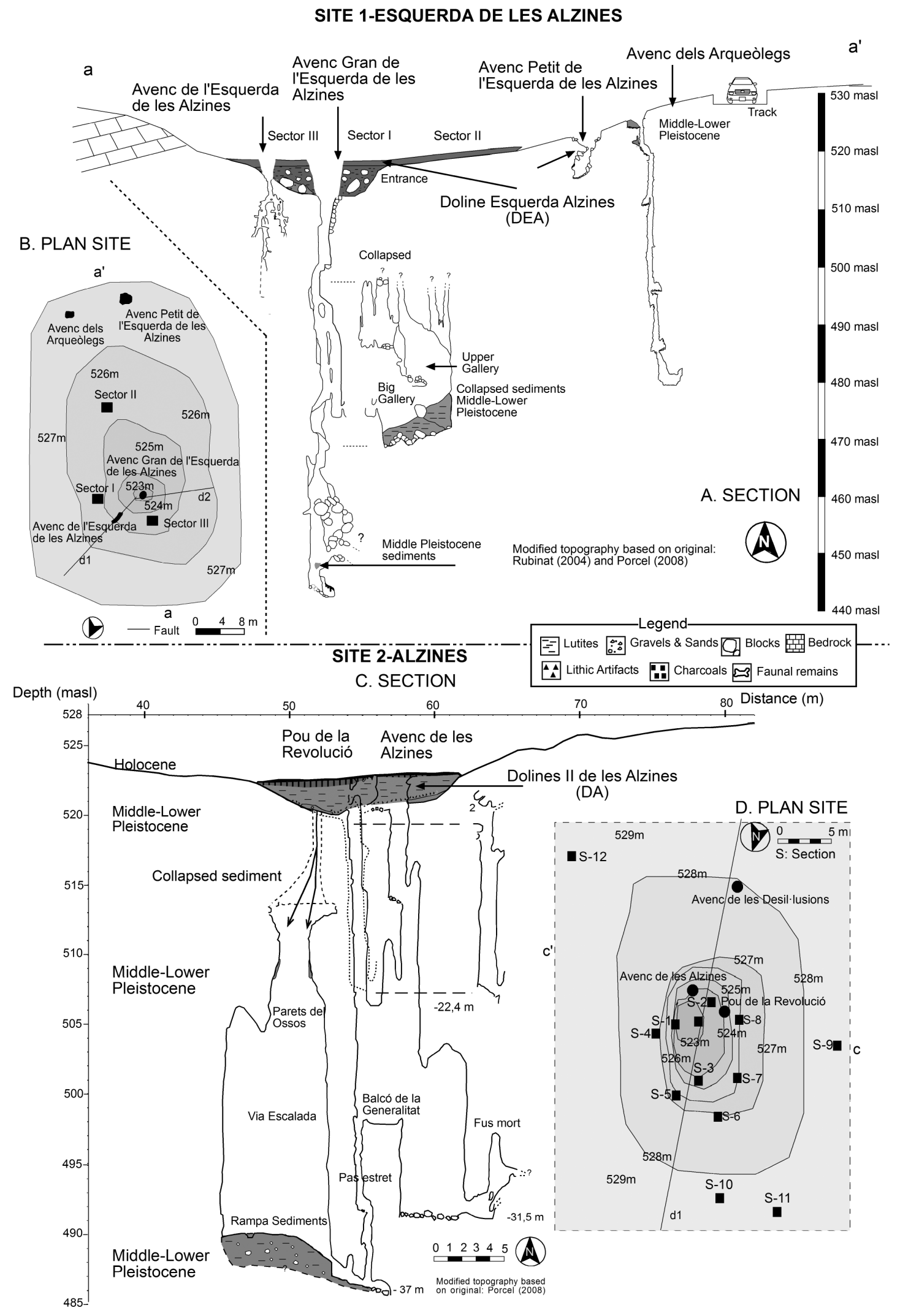

Figure 3. Cross-section (A) and plan (B) of site 1, Esquerda de les Alzines, and Cross-section (C) and plan (D) of site 2, Dolina II de las Alzines. 

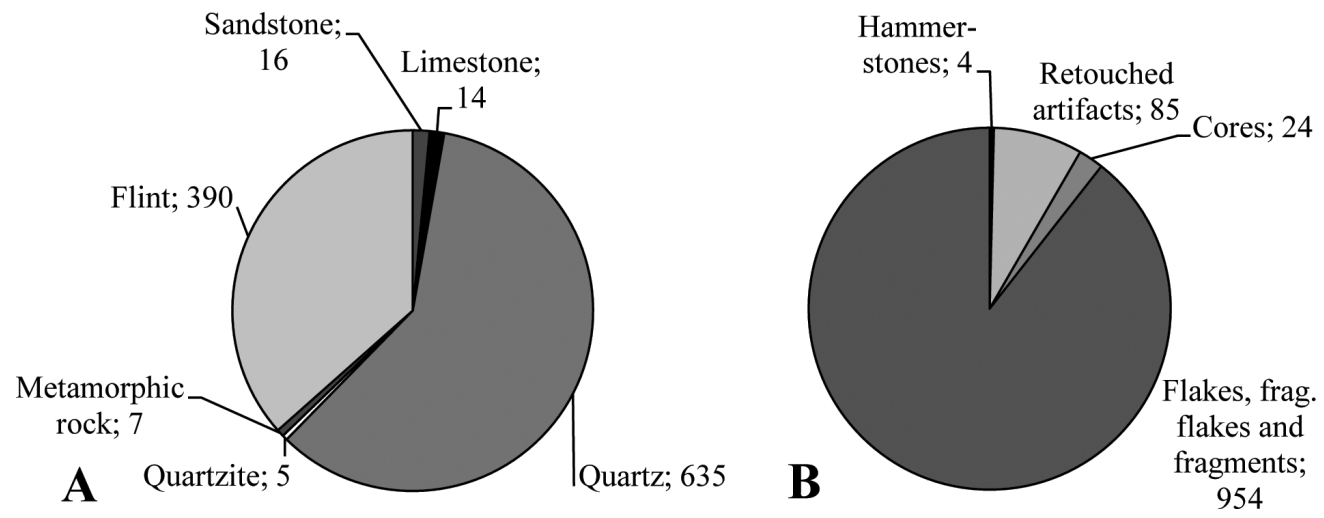

Figure 4. Site 1, Esquerda de les Alzines, raw materials (A) and structural categories (B) of stone artifacts based on Daura et al. (2011).

Archaeo-palaeontological remains were subsequently discovered at sites 1 and 2. At DEA, the excavation focused on a twenty-square-meter area using standard archaeological methods, including three-dimensional plot- ting of finds and their features. Archaeological remains were mapped in situ prior to removal, and sediments were dry-sieved using superimposed 5 and $0.5 \mathrm{~mm}$ mesh screens.

Table 1. Faunal remains recovered from the bases of dolines and inside of shafts, as well as from other caves that have an opening to the Garraf plateau.

\begin{tabular}{|c|c|c|c|}
\hline \multicolumn{4}{|c|}{ Plateau Sites } \\
\hline Site 2, Alzines & Site 3, Cova Bonica & Site 4, Avenc Marcel & Coll Sostrell \\
\hline $\begin{array}{l}\text { Perissodactyla } \\
\text { Stephanorhinus etruscus }{ }^{\mathrm{a}} \\
\text { Artiodactyla } \\
\text { Cervidae sp. } \mathrm{I}^{\mathrm{a}} \\
\text { Caprinae indet } \mathrm{a}^{\mathrm{a}} \\
\text { Carnivora } \\
\text { Ursus sp. } \\
\text { Lynx sp. }\end{array}$ & 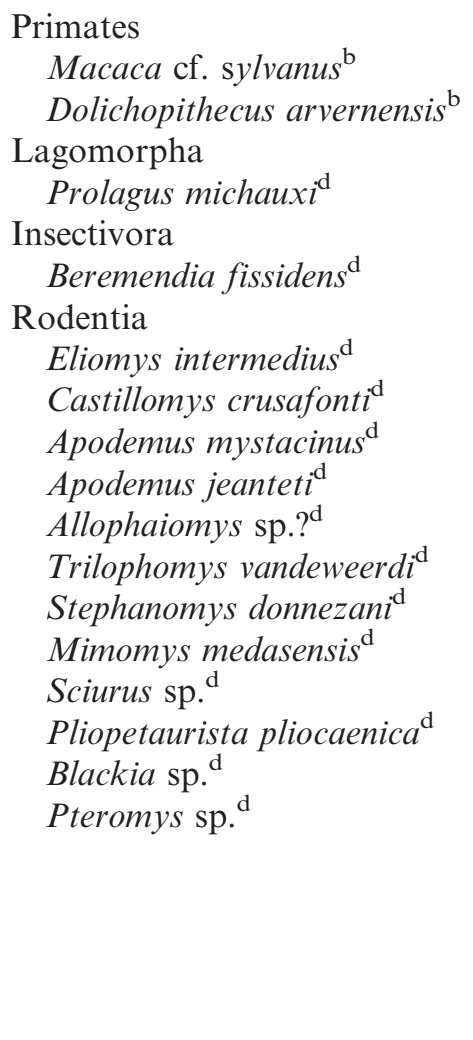 & 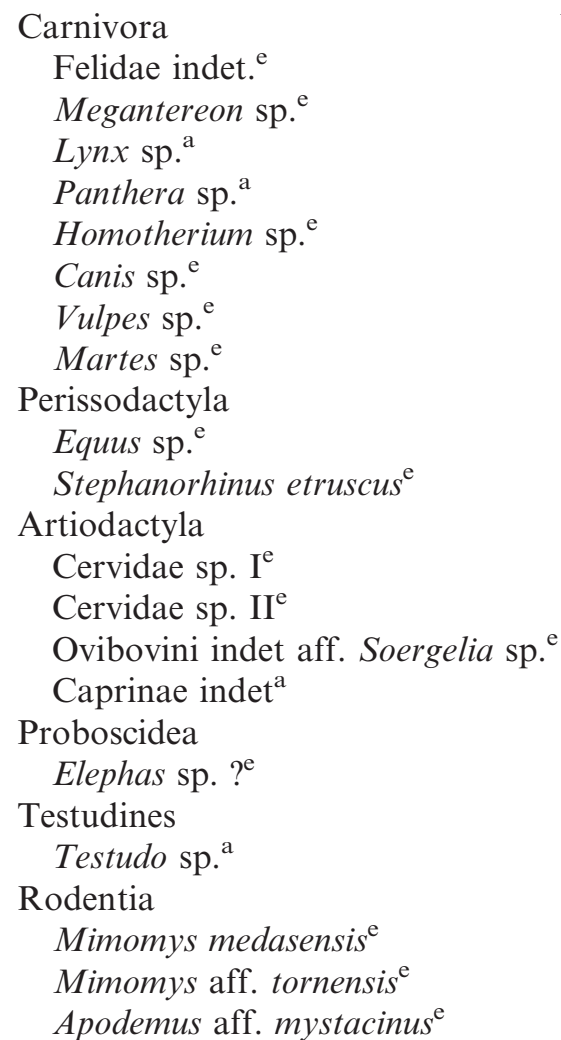 & Unidentified $^{\mathrm{a}}$ \\
\hline
\end{tabular}

${ }^{\text {a }}$ Daura (2008).

b Delson (1971; 1973; 1974), Crusafont and Golpe-Posse (1974) and Delson and Plopsor (1975).

c Agustí (1988).

${ }^{\mathrm{d}}$ Described here for the first time, following the identification currently listed in the collections of the Museu de Geologia de Barcelona (MGB).

e Asensio (1993). 
Karst evolution of the Garraf Massif (Barcelona, Spain): doline formation, Chronology and archaeo-Palaeontological ARCHIVES

SITE 3-AVENC MARCEL
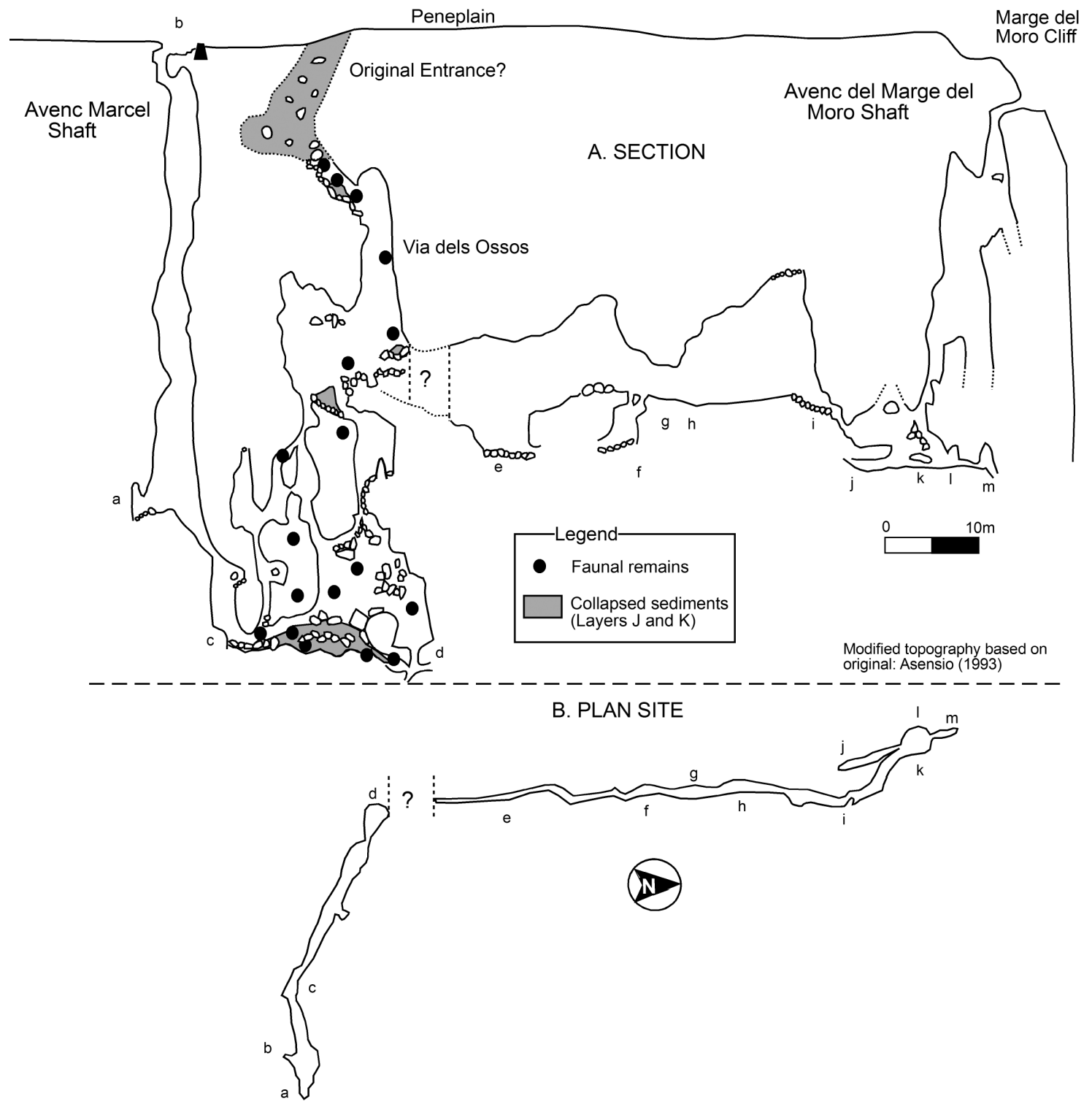

Figure 5. Cross-section (A) and plan (B) of site 3, Avenc Marcel.

At DA, levels presenting palaeontological remains comprise very compact, hard calcareous breccias that are cemented at the doline base. According to the methodological proposals made by Ramos et al. (2008) for sites of this type, excavation should involve the removal of sediment in different blocks. Using hammers and chisels, each recovered block was taken to the archaeological laboratory of the Grup de Recerca del Quaternari at the Seminari d'Estudis i Recerques Prehistòriques (la Guixera) operated by the Castelldefels Town Council, treated, and excavated with a pneumatic microhammer.

At a later date, a speleological expedition was undertaken by the GRQ and the Secció Espeleòlogica de l'Ordal del Centre Excursionista de Vallirana to detect any new cavities (Avenc de les Desil-lusions at site 2 and Avenc dels Arqueòlegs at site 1; Fig. 3) and to explore caves (Cova Bonica and Avenc Marcel; Fig. 2) and shafts under the Garraf plateau. A topographical and geological study was also carried out to determine the evolution of the doline and karst plain and the relationship between the endokarst and exokarst morphologies.

Sediment dates were analyzed by optically stimulated luminescence and thermoluminescence at the Radiochemistry and Dating Laboratory of the Universidad Autónoma de Madrid using the additive dose method and standard procedures (Fleming, 1970; Zimmerman, 1971; Aitken, 1985; Nambi and Aitken, 1986; Arribas et al., 1990) and by ${ }^{14} \mathrm{C}$ at the Beta Analytic Laboratory, USA. To determine the age of materials beyond the radiocarbon and the OSL dating limits, the palaeonto- 
logical records from Avenc Marcel, DEA, Coll Sostrell, and Cova Bonica were also included in the study. The latter are based on previous studies (Delson, 1971, 1973, 1974; Delson and Nicolaescu-Plopsor, 1975; CrusafontPairó and Golpe-Posse, 1984; Agustí, 1988; Asensio, 1993; Daura, 2008).

\section{RESUlts}

\section{Stratigraphic Setting}

Sedimentary fill from site 1, the Dolina de l'Esquerda de les Alzines, is the most significant for stratigraphic reconstruction. Current fieldwork focused on the excavation of five test pits (Fig. 3), two in sectors I, II and III, and one in the Avenc dels Arqueòlegs area (Fig. 6). The results form a single, unified sequence $4.5 \mathrm{~m}$ in length, but the correlations between the pits are merely tentative, given the discontinuities between them.

The lowest unit corresponds to highly cemented breccia and conglomerates (layers E, G1 and I), with a reddish, silty matrix formed by decalcification. The coarsest fraction is highly weathered and rounded by dissolution and typically contains sparitic calcite fragments, consisting of large dogtooth spar crystals of unusually high purity and crystallinity. Layer $\mathrm{H}$, above, is composed of non-cemented, compact lutites, separated from the upper part of the sequence by sub-angular boulders.

At the top of the sequence, layers C, C2, D2, B1, D1, B, and $\mathrm{D}$, infillings are typically characterized by deposits up to 2-m thick (Table 2), corresponding to lutites that are occasionally burned, with almost non-existent host rock components, indicative of the high degree of solution activity in the doline formation process. In fact, silt-size grains of quartz are predominant in the samples analysed (84.2 to $90.6 \%$ ) followed by feldspars (4.9 to $10.6 \%$ ), while host rock fragments are very scarce ( 0 to $5.2 \%)$. Illite is present in minor amounts ( 0 to $4.5 \%$ ).

The uppermost layer, layer 1 , contains $10-$ to $20-\mathrm{cm}$ thick superficial, rounded and sub-angular limestone gravel without lutites and may represent the current soil layer. The stratigraphy is summarized in Table 2 and illustrated in Figure 6.

Site 2 was studied via thirteen test pits (Fig. 3). The idealized schematic profile presented in Figure 6 shows similarities to DEA. Moreover, three broad episodes of sedimentation can be identified. The underlying layer $\mathrm{E}$ is composed of cemented breccia and conglomerates with sparitic calcite fragments adhered to the bedrock, representing the earliest deposition found in test pit S-11, which collapsed along Pou de la Revolució into the subterranean network. This unit contains bones of large mammals from the Lower Pleistocene that apparently fell from the Paret dels Ossos. The second package, layer $\mathrm{D}$, is composed mainly of cemented red clay with iron oxides and without a coarse fraction. On top, subsequent layers C and B are dominated by a lutitic matrix without gravels and contain a few small pieces of rubified sediment and sparse Holocene faunal remains. The uppermost $10 \mathrm{~cm}$ comprise the current soil layer and contain sub-angular limestone gravels.

Other sites, because they do not present a complete stratigraphic sequence, are less significant to our understanding of the sedimentary fill on the Garraf plateau. However, these units constitute the oldest stratigraphic levels exposed. Sedimentary fills that contain fossil remains have been identified in the subaerial exposure of cemented breccia in Coll Sostrell (layer K); in very highly cemented breccia adhered to external cave walls (layer K) and infiltrated from the Garraf karst plain (layer J) at site 4, Cova Bonica; and in cemented red breccia (layer $\mathrm{K}$ ) and compacted lutites with iron oxides (layer J) at Site 3, the Avenc Marcel.

Sediment collapses into the underlying cavities are common in the Garraf system. Stratigraphic correlations between the external and internal sediments are tentative, given the major discontinuities, including the Big Gallery in site 1 and the Parets del Ossos in site 2 (Fig. 3).

\section{DATING}

Our dating of the doline and shaft fill under the Garraf plateau indicates a chronology ranging between the Pliocene and Holocene. Seven radiometric dates were obtained from test pits, two ${ }^{14} \mathrm{C}$ dates on charcoal and bone and five optically stimulated luminescence dates on sediment. These, along with one thermoluminescesence date, are presented in Table 3 and discussed below. The dating of the doline deposits is hindered by taphonomic and geological processes, the absence or scarcity of organic material, and wildfire disturbance of sediments.

To determine the age of the first sediment accumulation in the plateau, the chronological range of the mammalian species present in Cova Bonica (site 4) and Avenc Marcel (site 3) is clearly diagnostic of Pliocene and Lower Pleistocene contexts (Fig. 7). Avenc Marcel (Fig. 5) developed on this ancient surface, and its sedimentary fill originated from the ancient plateau base, which contains Lower Pleistocene faunal remains. The different species of the genus Mimomys found here suggest a chronology between MN17 and MQ1 for this site (Asensio, 1993). Similarly, the Cova Bonica fill originating from the karst plateau includes a richness of small vertebrate species and Cercopithecidae remains. The remains recovered present a two-stage chronology, MN15 and MN17/MQ1 (Delson, 1971, 1973, 1974; Delson and Nicolaescu-Plopsor, 1975; CrusafontPairó and Golpe-Posse, 1984; Agustí, 1988; Blain, 2009). Coll Sostrell is a karst fissure associated with the plateau. Its conglomerate and breccia deposits contain faunal remains from the Lower Pleistocene (Daura, 2008). Finally, rhinoceros remains assigned preliminarily to Stephanorhinus etruscus from Pou de la Revolució at site 2 date the site from MN16 to the beginning of the Middle Pleistocene (Guérin, 1980; van der Made, 2010; van der Made and Grube, 2010). 
Karst evolution of the Garraf Massif (Barcelona, Spain): doline formation, Chronology and archaeo-Palaeontological ARCHIVES

SITE 1-ESQUERDA DE LES ALZINES
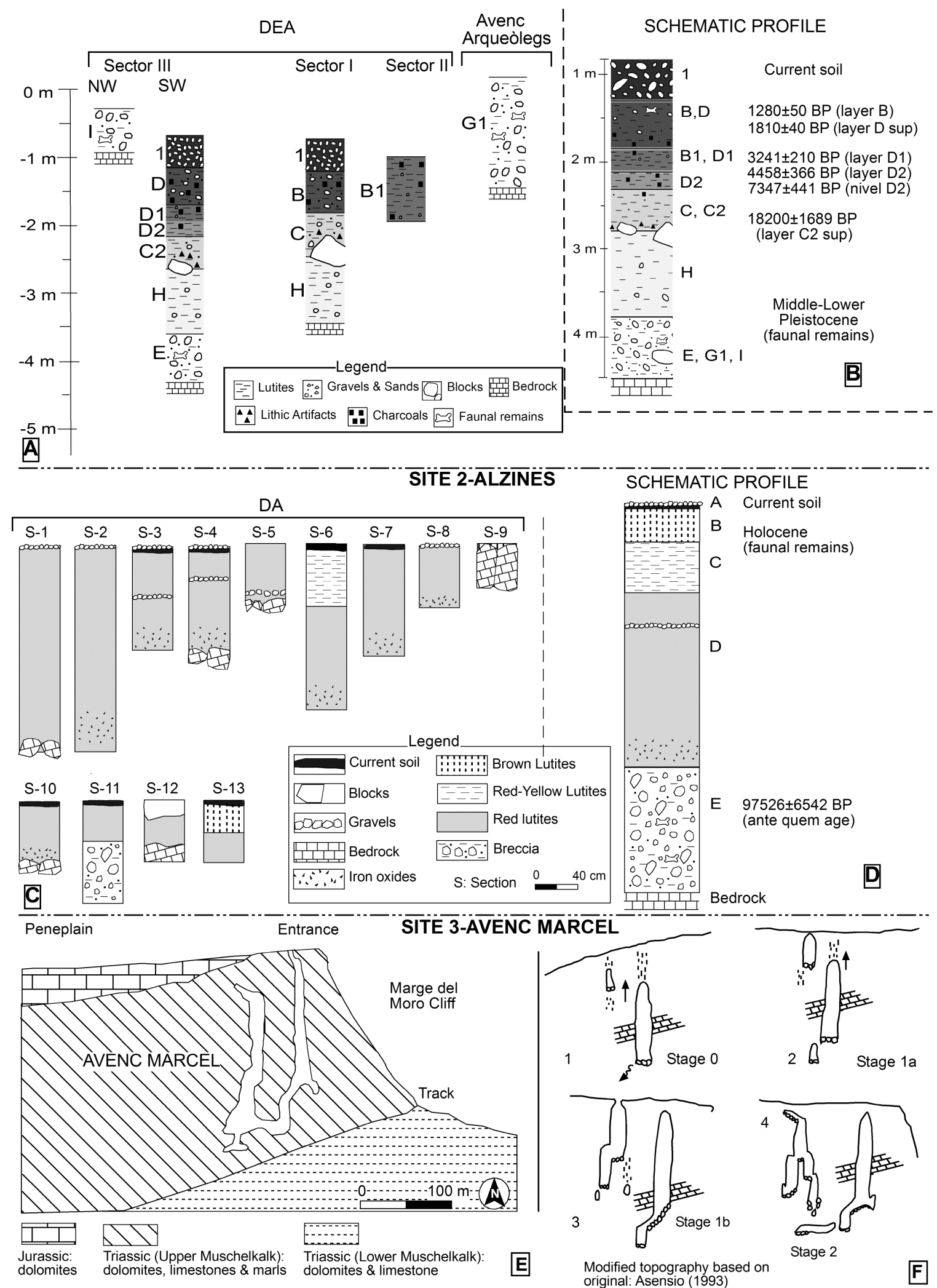

Figure 6. Site 1, Esquerda de les Alzines: A, stratigraphy of individual locations; B, assembled schematic profile with suggested chronology. Site 2, Alzines: C, stratigraphic test pits dug; D, assembled schematic profile with suggested chronology. Site 3, Avenc Marcel: E, shaft geological cross-section of the plateau; F, proposed evolutionary model for the formation of the site during Pliocene and Lower Pleistocene stages. 


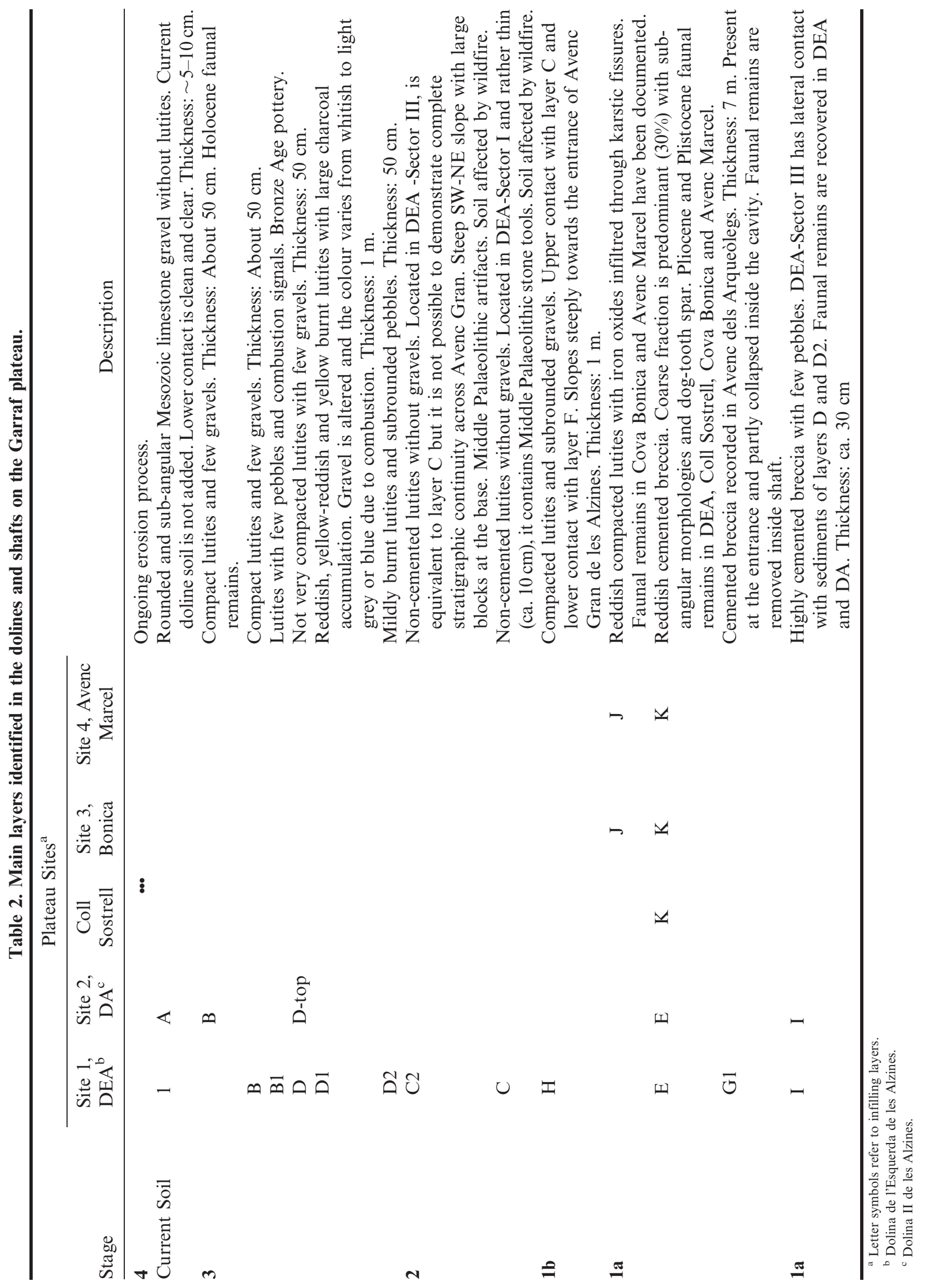


Karst evolution of the Garraf Massif (Barcelona, Spain): doline formation, Chronology and archaeo-Palaeontological ARCHIVES

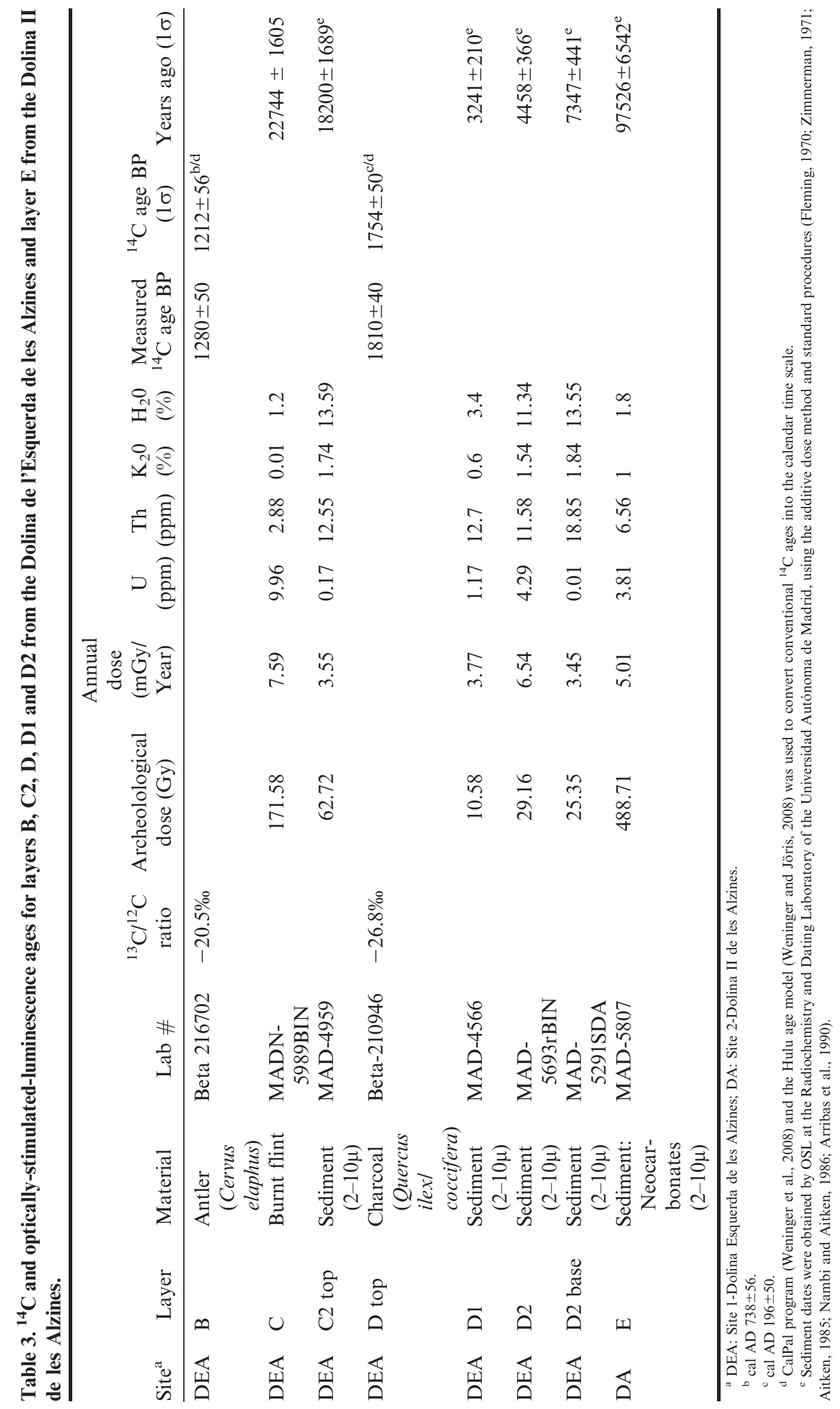




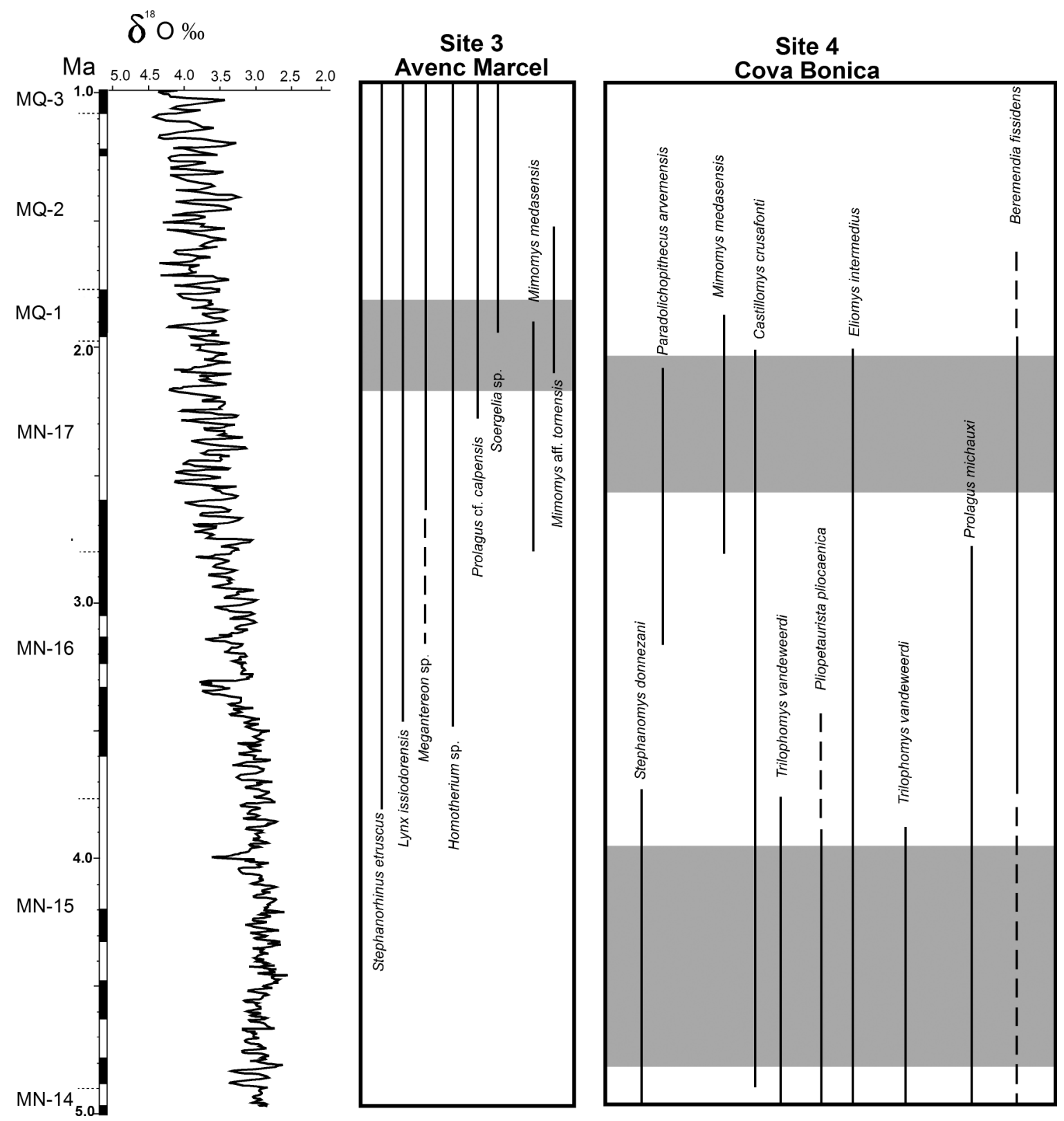

Figure 7. Vertical distribution of the main taxa identified at site 3, Avenc Marcel (Asensio, 1993; Daura 2008), and site 4, Cova Bonica. Small mammals from Cova Bonica are described here for the first time, following the identification currently listed in the collections of the Museu de Geologia de Barcelona and Agustí, (1988) whereas the Cercopithecidae have been previously described (Delson, 1971, 1973, 1974; Delson and Nicolaescu-Plopsor, 1975; Crusafont-Pairó and Golpe-Posse, 1984). Age in millions of years (Ma), Mammal Neogene Units (MN) (Agustí, 2001) and oxygen isotope curve (Shackleton et al., 1995) on the left. The vertical lines highlight the chronological ranges based on current literature for large mammals (Pickford and Morales, 1994; van der Made, 2005; Martínez-Navarro et al., 2010; Rook and Martínez-Navarro, 2010) and micromammals (Minwer-Barakat et al., 2004; de Marfà, 2009; Furió, 2007; García-Alix et al., 2007; Minwer-Barakat et al., 2008). Gray rectangle indicates the chronostratigraphic range proposed for the site.

The oldest absolute date for the sediments at the base of the dolines was found in layer $\mathrm{E}$ of the Dolina II de les Alzines (site 2). A multi-grain OSL average date of $97526 \pm 6542 \mathrm{BP}$ was obtained. However, the result should be treated with some caution given, the method used (not single-grain) and the taphonomy of the sediments.
More recent layers have been Dated using other techniques. Layers $\mathrm{C}$ and $\mathrm{C} 2$ at the the Dolina de l'Esquerda de les Alzines (site 1) contain lithic artifacts that are chronologically dated to the Middle or Upper Palaeolithic techno-complex (Daura et al., 2011). A thermoluminescence date for burnt flint from layer $\mathrm{C}$ gives 
Karst evolution of the Garraf Massif (Barcelona, Spain): doline formation, Chronology and archaeo-Palaeontological ARCHIVES

an age of $22744 \pm 1605 \mathrm{BP}$, and an OSL date is $18200 \pm 1689$ BP for sediment from the top of layer $\mathrm{C} 2$.

The DEA continued to be filled throughout the Upper Pleistocene and Holocene, from $>22.7 \mathrm{ka}$ until the present. However, several wildfires occurred during this time, affecting different layers and altering the sediments. As a result, reliable direct OSL dates are not easily obtained, as fires can make sediment appear younger, especially because of burnt tree stumps. Nonetheless, these dates (Table 3) are indicative of an ante quem age for the fill that is older than the dates obtained both by OSL ( $7 \mathrm{ka}$ to $3 \mathrm{ka}$ ) and radiocarbon dating (cal AD $738 \pm 56$ and 196 \pm 50 ). The presence of Bronze and Iron Age pottery in Layers B1 and D1 provide an approximate chronology for the accumulation of these deposits in accordance with OSL results.

\section{A Model of Landscape Development AND KARSTIFICATION}

Attempts were made to correlate the various dolines and shafts on the basis of their layers, stratigraphic position, and chronology. This correlation remains tentative because of the discontinuities between the various deposits and the shortcomings presented by each deposit. Our stratigraphic study identifies five stages or episodes resulting in the formation of a single unified sequence (Fig. 8). Its backbone is formed by the sediments preserved in the Dolina de l'Esquerda de les Alzines and the Dolina II de les Alzines, while the Cova Bonica, Avenc Marcel, and Coll Sostrell sites represent significant deposits for determining the ancient stage of the Garraf plateau.

Stage 0 corresponds to the formation of the Garraf plateau during the Upper Miocene that resulted in the horizontal modelling of the landscape (Llopis, 1943, 1947; Montoriol, 1950, 1954; Montoriol and Muntan, 1959, 1961). As such, the conditions required to trigger the doline formation process were present during this stage, despite the fact that no sediment had yet accumulated. The result of this stage is the presence of some monadnock-shaped standing remains.

Stages $1 \mathrm{a}$ and $1 \mathrm{~b}$ correspond to the oldest sediment accumulations in the plateau, dating from between the Pliocene and Lower Pleistocene. The process of doline and shaft fill is confirmed by the presence of the most ancient deposits located at the base of the dolines and the sediments collapsed into the shafts. In the earlier part of the stage (1a), the first layer (G1) of sediments in the DEA lies at the base of the Avenc dels Arqueòlegs area and has partially collapsed into the subterranean network. The lower contact is irregular and overlies the Cretaceous limestone. In the latter part of the stage (1b), layers are also found in the Avenc (shaft) de l'Esquerda de les Alzines (layer I) and in Sector III-W at the base of the doline's center (layer E), as well as in the DA, which contains mammal bones. In this case, deposits are located near Pou de la Revolució (Fig. 3), and part of the fill collapsed into the shaft through the Parets dels Ossos.

Infilling of similar material that probably originated from a collapsed surface deposit is found adhered to the walls in Via del Ossos of the Avenc Marcel shaft. The fill contains mammal bones and has been scattered throughout the subterranean network from which palaeontological remains were recovered. Finally, the Cova Bonica fill originates from sediment infiltration from the plateau through a combination of karst fissures and karren.

Stages 2 and 3 correspond to the second layers of deposits to accumulate. After the oldest sediment, those of stage 1 (layers E, G1, and I) developed, parts of these sediments were altered by the evolutionary process undergone by the depression. In some areas, fill from stage 1 was cemented and preserved at the rim of the doline or inside its shafts, as well as in layer E of the DEA (Fig. 3 and 6) and the base of the DA. In other cases, shafts received part of the collapsed sediment, as is the case in the DA (Fig. 6).

Stage 1 sediments found at the doline base are always capped by stage 2 layers. The most significant examples of stage 2 are layers $\mathrm{C}$ and $\mathrm{C} 2$ in the DEA. They contain Upper Palaeolithic artifacts such as burins, denticulates, and scrapers, among others.

The final sediment layer (stage 3 ) is characterized by highly compact lutites with few pebbles and gravels. These have been altered by wildfire combustion in sectors I, II, and III-SW in the DEA, a distortion in this area that is only limited by a gentle slope. Layers B, B1, and D1 of this unit contain prehistoric pottery. One layer, composed mainly of rounded sub-angular limestone gravels, corresponds to the current doline soil.

Stage 4 corresponds to the ongoing erosion process in which the dolines are being continuously transformed by agricultural or speleological activities.

\section{Discussion And Conclusions}

The results obtained from the Garraf case study coincide with proposals made for other European karst massifs (Piccini et al., 2003; Ufrecht, 2008) that the primary karst development appears to have taken place at the end of the Tertiary and the beginning of the Lower Pleistocene. The main karst features around the western Mediterranean were probably inherited from the end of the Miocene (Messinian period), when the sea level dropped dramatically due to the closing of the Atlantic connection and the subsequent desiccation of the Mediterranean sea (Krijgsman et al., 1999). The depths and altitudes of several conduits and galleries in karst areas around the western Mediterranean that do not match known Quaternary glacio-eustatic sea levels are linked to the erosive features observed during the Miocene and the Pliocene (Audra et 
GARRAF PLATEAU

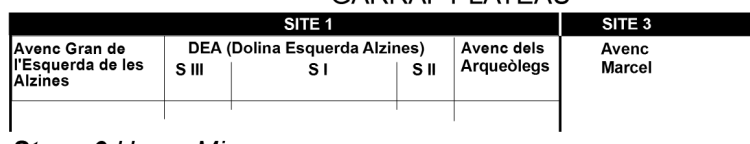

Stage 0 Upper Miocene

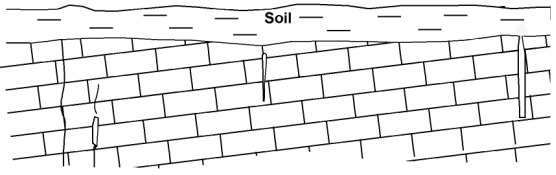

Stage 1a Pliocene-Lower Pleistocene 0
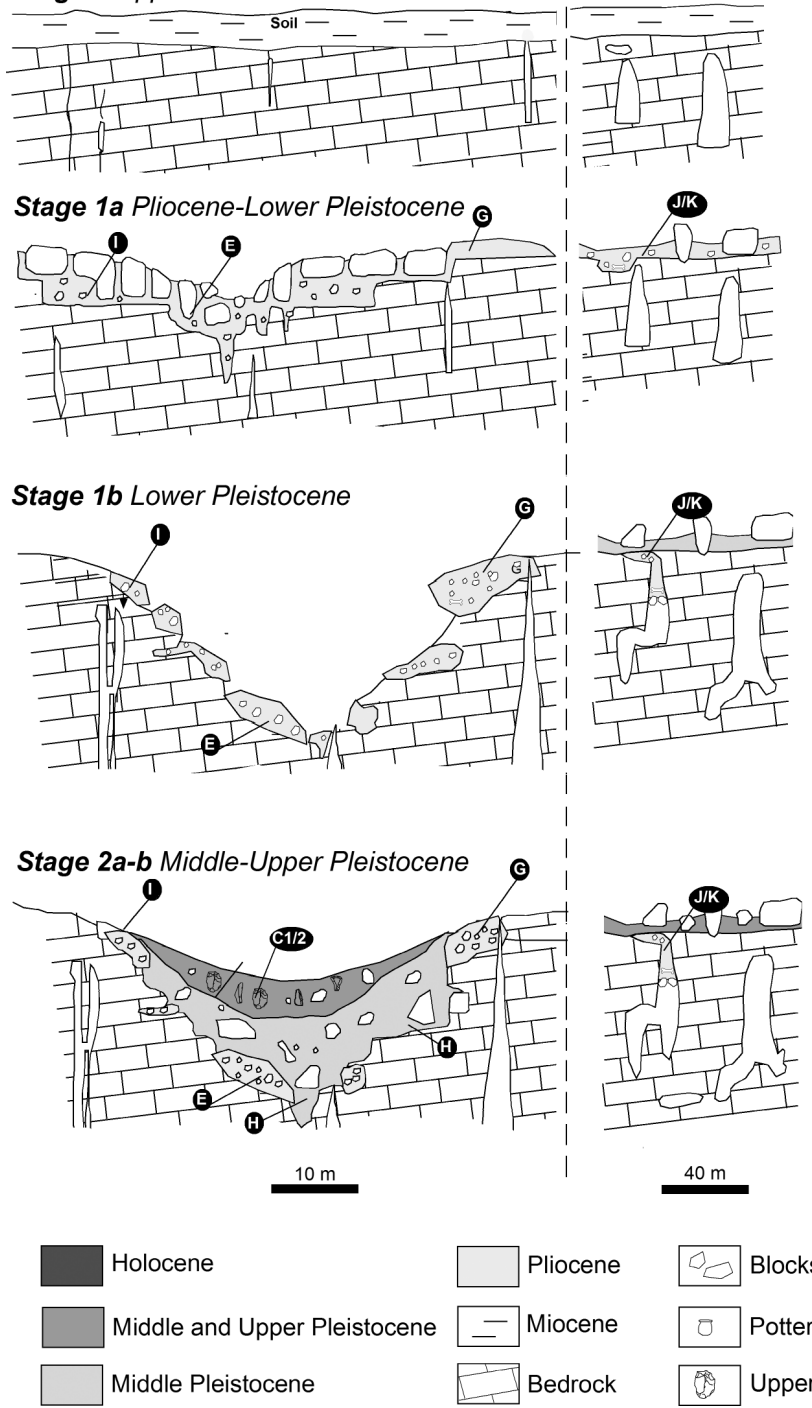

GARRAF PLATEAU

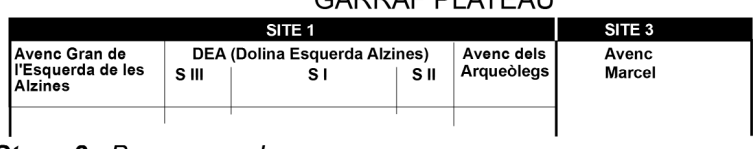

Stage 3a Bronze age-Iron age

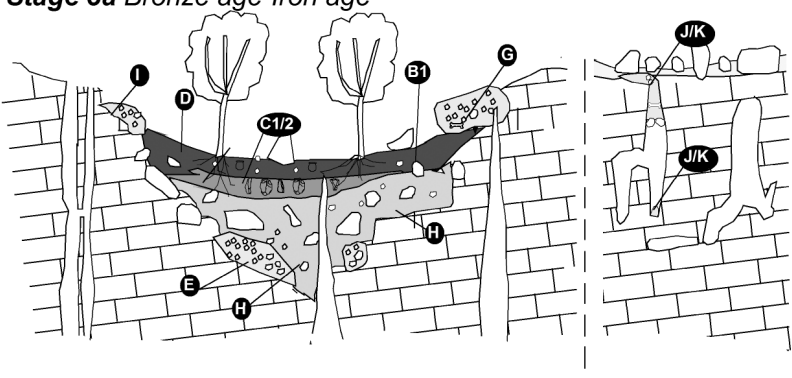

Stage $\mathbf{3 b}$ Iron age-Medieval and Modern age

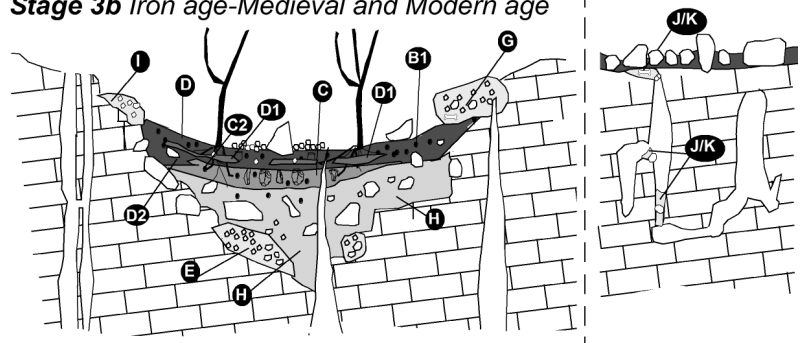

Stage 4 Present day
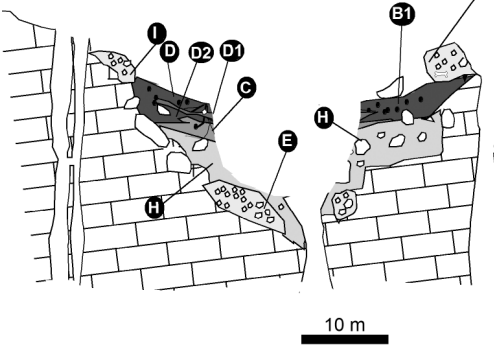

Fु Faunal remains

$\square$ Erosive process

Shaft

Figure 8. Characteristic stages of Garraf doline evolution, according on hypothesis based data obtained at the different dolines and shafts studied and applied to various parts of site 1, Dolina Esquerda de les Alzines, and site 3, Avenc Marcel. The labels on the sediment levels are those in Figure 6 and the text.

al., 2004). These karst paleo-galleries evolved after the subsequent Pliocene sea level rise and transgression, flooding the former karst system. Later oscillations of the water table, forced by the Quaternary eustatic sea-level changes, favored the evolution of the karst depressions and the sedimentary infill of the former karst system above the water table.

Previous research has argued in favor of a general Miocene age for the Garraf plateau (Llopis, 1943, 1947; Montoriol, 1950, 1954; Montoriol and Muntan, 1959, 1961). Based on the sediments preserved, we can confirm that the doline and shaft infill originating from the Garraf plateau can be dated to the beginning of the Pliocene (stage 1) and, hence, earlier karstification processes must have taken place during the Miocene (stage 0 ), when conditions were suited to triggering the doline-formation process. The Garraf deep karst system was probably formed during the Messinian period ( -5.96 to $-5.32 \mathrm{Ma}$ ) and was reflooded during the Pliocene when the Mediterranean salinity crisis terminated (Audra et al., 2004). In fact, the discharge point for water draining out of the Garraf massif is La Falconera shaft, at least $81 \mathrm{~m}$ below the present sea level, suggesting that karstification occurred during this period of lower sea level (Montoriol, 1966; Custodio, 1975; Cardona, 1990). 
Karst evolution of the Garraf Massif (Barcelona, Spain): doline formation, Chronology and archaeo-Palaeontological ARCHIVES

Palaeopalynological studies (Suc and Cravatte, 1982; Suc et al., 1995; Fauquette et al., 1999) emphasize a subtropical climate for the northwestern Mediterranean during the Pliocene, and these environmental conditions could have accelerated karstification.

Palaeontological remains from stage 1 indicate an age of MN15 and MN17 (Delson, 1971, 1973, 1974; Delson and Nicolaescu-Plopsor, 1975; Crusafont-Pairó and GolpePosse, 1984; Agustí, 1988; Asensio, 1993; Daura, 2008). Today, sediments from this stage are located within the deepest inner part of the Garraf karst and have been eroded from their original position in the Garraf plateau. In this sense, the Canal Negre-1 (Guillén, 2010) assemblage could represent the earlier sediment accumulation, from stage 1 to the Upper Miocene (MN13).

The species richness at the paleontological sites Cova Bonica, Avenc Marcel, and Canal Negre-1 and the results of the pollen analyses (Suc and Cravatte, 1982; Suc et al., 1995; Fauquette et al., 1999) point to ecological optima in the Garraf plateau during the Pliocene, a different scenario from the current habitability of this area. Thus, dolines and collapsed cavities under the plateau are a useful record for Quaternary paleoenvironmental studies.

During the Middle-Upper Pleistocene (stage 2), significant sediment deposits accumulated in the dolines and shafts of the Garraf karst plateau. Infill of the same chronology is common beyond the plateau in other karst landforms, including the caves of Cova del Gegant (Daura et al., 2010a), Cova del Rinoceront (Daura et al., 2005), and Cova del coll Verdaguer (Daura et al., 2010b). However, in the karst plateau sediment has collapsed down into the subterranean network, suggesting that archaeological and paleontological records must be sought in the deeper levels of the karst system. This conclusion is supported by a large number of sites in the Iberian Peninsula, including the Almonda system in the Maciço Calcário Estremenho (Zilhão et al., 1993; Hoffmann et al., 2013), El Sidrón in Surco Oviedo-Infiesto (Rosas et al., 2006), the Sierra de Atapuerca (Rosas et al., 2001), and Cueva del Ángel in the Sierra de Araceli (Barroso Ruíz et al., 2011), among others.

A marked gap should be noted between the PlioceneLower Pleistocene and the Middle-Upper Pleistocene, with sedimentary deposits from this period being unknown in the Garraf plateau and in other caves and shafts of the Garraf Massif. There are three possible explanations for this: the sediments collapsed into the inner karst system through vertical shafts, no sedimentary processes occurred, or the phase has yet to be documented. However, we speculate that the sediments accumulated at the Big Gallery of Avenc Gran de les Alzines in site 1 and at the base of Rampa Sediments in site 2 could be dated to this period.

The Garraf Massif and the five stages identified here in its evolution point to the importance of karst development and sediment displacement for archaeological and paleontological studies, especially for the detection and evaluation of the viability of a karst plateau as an area of hominid presence (Bourguignon, 2004; Mosquera et al., 2007) because of its faunal or water resources.

Our results, based on geomorphologic arguments and sediment dating, are more accurate, we believe, than the previously proposed estimates of the age of Garraf doline and karst landforms (Llopis, 1943, 1947; Montoriol, 1950, 1954; Montoriol and Muntan, 1959, 1961). We have been able to construct a model of the geomorphic evolution of the Garraf Massif dolines that resulted in a single and unified sequence (Fig. 8). This sequence spans the Pliocene to the Holocene and constitutes the first chronological proposal for the Garraf karst. Our study has provided new examples and important data regarding the speleogenetic processes and the chronology of western Mediterranean dolines, shafts and karst plateaus.

\section{ACKNOWLEDGEMENTS}

This paper forms part of two research projects, Humans, Carnívors i medi natural al Garraf and El Plistocè Superior $i$ l'Holocè a Catalunya, supported by 2014SGR-108 and 2009ACOM00090 (Generalitat de Catalunya), HAR201126193, CGL2010-18616 and CGL2009-07392 projects (MICINN-FEDER). Fieldwork was supported by Servei d'Arqueologia i Paleontologia (Generalitat de Catalunya) and Ajuntaments de Vallirana i Begues. J. Daura has been supported by a postdoctoral grant (Juan de la Cierva Subprogram, JCI-2011-09543) and M. Sanz by a predoctoral grant (FI) from the Comissionat per a Universitats i Recerca del Departament d'Innovació, Universitats i Empresa de la Generalitat de Catalunya, and the Fons Social Europeu. We are especially grateful to H. Martins (University of Bristol), Liana M. Boop (University of South Florida), and Vance T. Holiday (University of Arizona) for comments on the manuscript, the owners of the dolines (Can Pau de la Figuera estate) for their collaboration, and to the Grup d'Espeleologia Badalona and the Secció Espeleològica Ordal del Centre Excursionista de Vallirana for the speleological work. The authors would like to extend their thanks to X. Esteve and M. Yubero for the digitization of Figures 1 and $2 b$, respectively, and to editorial staff for their constructive comments.

\section{REFERENCES}

Agustí, J., 1988, Els cordats [excepte els primats homínids], in Gallemí, J., cord., Registre Fòssil. Història Natural dels Països Catalans: Barcelona, Fundació Enciclopèdia Catalana, v. 15, p. 389-427.

Agustí, J., 2001, Defining MN-units and magnetobiostratigraphic correlation of the Spanish sections, in Latal, C., and Pillar, W.E., eds., Environmental and Ecosystem Dynamics of the Eurasian Neogene (EEDEN); Stratigraphy \& Paleogeography Workshop March 15-18 2001, Graz, Austria: Graz, Berichte des Institutes für Geologie und Paläontologie der Karl-Franzens-Universität Graz, no. 4, p. 23-26.

Agustí, J., Cabrera, L., Garcés, M., Krijgsman, W., Oms, O., and Parés, J.M., 2001, A calibrated mammal scale for the Neogene of Western 
Europe. State of the art: Earth-Science Reviews, v. 52, p. 247-260. doi:10.1016/S0012-8252(00)00025-8.

Aitken, M.J., 1985, Thermoluminescence Dating. London, Academy Press, $359 \mathrm{p}$.

Albich, S., Bernaus, J.M., Boix, C., Caus, E., Martín-Closas, C., Salas, R., Vicedo, V., and Villalonga, R., 2006, Caracterización bioestratigráfica y paleoambiental del Cretácico inferior (Berraisiense-Barremiense) del Macizo del Garraf (Cadena Costera Catalana): Revista Española de Micropaleontología, v. 38, no. 2-3, p. 429-451.

Andreu, A., Calvet, F., Font, X., and Viladevall, M., 1987, Las mineralizaciones de $\mathrm{Pb}-\mathrm{Zn}-\mathrm{Ba}$ en el Muschelkalk inferior de los Catalánides: Cuadernos de Geología Ibérica, v. 11, p. 779-795.

Arribas, J.G., Millán, A., Sibilia, E., and Calderón, T., 1990, Factores que afectan en la determinación del error asociado a la datación absoluta por TL: Fábrica de ladrillos: Boletín de la Sociedad Española de Mineralogía, v. 13, p. 141-147.

Asensio, T., 1993, Cavidades del Pla del Marge del Moro: Nuevos descubrimientos en el Avenc Marçel: Passamà, v. 1, p. 27-42.

Audra, P., Mocochain, L., Camus, H., Gilli, E., Clauzon, G., and Bigot, J.-Y., 2004, The effect of the Messinian Deep Stage on karst development around the Mediterranean Sea. Examples from Southern France: Geodinamica Acta, v. 17, no. 6, p. 389-400. doi:10.3166/ ga.17.389-400.

Baroň, I., 2002, Speleogenesis along sub-vertical joints: A model of plateau karst shaft development: A case study: the Dolný Vrch Plateau (Slovak Republic): Cave and Karst Science, v. 29, no. 1, p. $5-12$.

Barroso Ruíz, C., Botella Ortega, D., Caparrós, M., Moigne, A.M., Celiberti, V., Testu, A., Barsky, D., Notter, O., Riquelme Cantel, J.A., Pozo Rodríguez, M., Carretero León, M.I., Monge Gómez, G., Khatib, S., Saos, T., Gregoire, S., Bailón, S., García Solano, J.A., Cabral Mesa, A.L., Djerrab, A., Hedley, I.G., Abdessadok, S., Batalla LLasat, G., Astier, N., Bertin, L., Boulbes, N., Cauche, D., Filoux, A., Hanquet, C., Milizia, C., Moutoussamy, J., Rossoni, E., Verdú Bernejo, L., and de Lumley, H., 2011, The Cueva del Angel (Lucena, Spain): An Acheulean hunters habitat in the South of the Iberian Peninsula: Quaternary International, v. 243, no. 1, p. 105-126. doi:10. 1016/j.quaint.2011.02.021.

Bartrina, M.T., Cabrera, L., Jurado, M.J., Guimerà, J., and Roca, E., 1992, Evolution of the central Catalan margin of the Valencia trough (western Mediterranean): Tectonophysics, v. 203, p. 219-247. doi:10. 1016/0040-1951(92)90225-U.

Benet, I., 1990, El Paleozoico de la parte NE del Macizo del Garraf (Cadenas Costeras Catalanas): Acta Geológica Hispánica, v. 25, no. 1-2, p. 133-139.

Blain, H.-A., 2009, Contribution de la paléoherpétofaune (Amphibia et Squamata) à la connaissance de l'évolution du climat et du paysage du Pliocène supérieur au Pléistocène moyen d'Espagne: Treballs del Museu de Geologia de Barcelona, v. 16, p. 39-170.

Blain, H.-A., and Bailon, S., 2006, Catalogue of Spanish Plio-Pleistocene amphibians and squamate reptiles from the Museu de Geologia de Barcelona: Treballs del Museu de Geología de Barcelona, v. 14, p. $61-80$.

Borràs, J., 1974, Catálogo Espeleológico del Macizo del Garraf: Barcelona, Ed. Limonograph, 3 vols.

Bourguignon, L., Ortega, I., Sellami, F., Brenet, M., Grigoletto, F., Vigier, S., Daussy, A., Deschamps, J.-F., and Casagrande, F., 2004, Les occupations paléolithiques découvertes sur la section Nord de la déviation de Bergerac: résultats préliminaires obtenus à l'issue des diagnostics: Préhistoire du Sud-Ouest, v. 11, no. 2, p. 155-172.

Bruxelles, L., Colonge, D., and Salgues, T., 2006, Morphologie et remplissage des dolines de Causse de Martel d'après les observations réalisées au cours du diagnostic archéologique de l'aérodrome de Brive-Souillac (Corrèze et Lot): Karstologia, v. 47, p. 21-32.

Bruxelles, L., Colonge, D., Jarry, M., and Pons, F., 2008, Climate change and human impacts: the dolines fillings of limestone plateaus of the south western of France, in: The Fifth International Conference, Climate Change: Karst Record. School of Geographical Sciences, Southwest University, Chongqing, China, Abstract Volume, 106 p.

Bruxelles, L., Colonge, D., and Salgues, T., 2012, Les dolines du Causse de Martel (Corrèze et Lot): études des remplissages et implications paléoenvironnementales: Géologues, v. 173, p. 23-27.

Cardona, F., 1990, Grans cavitats de Catalunya. El sistema mediterrani i la depressió central: Barcelona, Espeleoclub de Gràcia, 484 p.
Crusafont-Pairó, M., and Golpe-Posse, J.M., 1984, Nuevo hallazgo de macaco en Cova Bonica (Gavà): Acta Geológica Hispánica, v. 19, no. 1, p. 29-32.

Custodio, E., 1975, Metodología y resultados del estudio hidrogeológico del macizo kárstico de Garraf, Barcelona: Boletín Geológico y Minero, v. 86 , no. 1 , p. $31-44$.

Custodio, E., Bayo, A., Pascual, M., and Bosch, X., 1993, Results from studies in several karst formation in southern Catalonia (Spain), in Proceedings of the Antalya Symposium and Field Seminar, October, 1990, IAHS Publ. no. 207, p. 295-326.

Cvijić, J., 1893, Das Karstphänomen. Versuch einer morphologichen Monographie: Geographische Abhandlungen heruasgegeben von Prof. Dr. A. Penck, v. 5, no. 3, p. 218-329.

Daura, J., 2008, Caracterització arqueològica i paleontològica dels jaciments plistocens del massís del Garraf-Ordal i curs baix del riu Llobregat [Ph. D. thesis]: Barcelona, Universitat de Barcelona, $674 \mathrm{p}$.

Daura, J., and Sanz, M., 2010, Memòria de les intervencions arqueològiques a la Dolina II de les Alzines-Can Pau de la Figuera (Begues-Vallirana, Baix Llobregat): Unpublished Archaeological Report, Barcelona, Servei d'Arqueologia i Paleontologia, Departament de Cultura i Mitjans de Comunicació, Generalitat de Catalunya, $85 \mathrm{p}$.

Daura, J., Sanz, M., Pike, A.W.G., Zilhão, J., Subirà, M.E., Fornós, J.J., Fullola, J.M., and Julià, R., 2010a, Stratigraphic context and direct dating of the Neandertal mandible from Cova del Gegant (Sitges, Barcelona): Journal of Human Evolution, v. 59, no. 1, p. 109-122. doi:10.1016/j.jhevol.2010.04.009.

Daura, J., Sanz, M., Rosell, J., and Julià, R., 2010b, La Cova del Coll Verdaguer (Cervelló, Barcelona): Un cubil de hiena y osos con presencia de humana durante del Paleolítico Medio, in Baquedano, E., and Rosell, J., eds., Proceedings of the I Reunión de científicos sobre cubiles de hienas (y otros grandes carnívoros) en los yacimientos arqueológicos de la Península Ibérica: Zona Arqueológica, v. 13, p. $502-507$.

Daura, J., Sanz, M., and Vaquero, M., 2005, El Pleistoceno de la Cova del Rinoceront (Castelldefels, Barcelona), in Ferreira-Bicho, N., ed., O Paleolitico. Proceedings of the IV Congresso de Arqueologia Peninsular: Faro, Universidade do Algarve, Promontoria Monográfica, v. 2, p. 217-227.

Daura, J., Sanz, M., Vaquero, M., and Fullola, J.M., 2011, La Dolina de l'Esquerda de les Alzines (Macizo del Garraf, Barcelona): un yacimiento del Pleistoceno superior al aire libre con industria lítica paleolítica: Trabajos de Prehistoria, v. 68, no. 2, p. 353-367. doi:10.3989/tp. 2011.11074.

Delson, E., 1971, Estudio preliminar de unos restos de simios pliocénicos procedentes de "Cova Bonica" (Gavà), (Prov. Barcelona): Acta Geológica Hispánica, v. 6, no. 2, p. 54-57.

Delson, E., 1973, Fossil Colobine Monkeys of the circum-mediterranean region and the revolutionary history of the Cercopithecidae (Primates, Mammalia) [Ph. D. thesis]: New York, Columbia University, $856 \mathrm{p}$.

Delson, E., 1974, Preliminary review of Cercopithecid distribution in the Circum Mediterranean Region: Mémoires du Bureau de Récherches Géologiques et Minières, v. 78, no. 1, p. 131-135.

Delson, E., and Nicolaescu-Plopsor, D., 1975, Paradolichopithecus, a large terrestrial monkey (Cercopithecidae, primates) from the PlioPleistocene of southern Europe and its importance for mammalian biochronology, in Proceedings of the 6th Session, Regional Committee on Mediterranean Neogene Stratigraphy: Bratislava, Slovak Academy of Sciences, p. 91-96.

Falguères, C., Bahain, J.-J., Tozzi, C., Boschian, G., Dolo, J.-M., Mercier, N., Valladas, H., and Yokoyama, Y., 2008, ESR/U-series chronology of the Lower Palaeolithic palaeoanthropological site of Visogliano, Trieste, Italy: Quaternary Geochronology, v. 3, no. 4, p. 390-398. doi:10.1016/j.quageo.2008.01.007.

Fauquette, S., Suc, J.-P., Guiot, J., Diniz, F., Feddi, N., Zheng, Z., Bessais, E., and Drivaliari, A., 1999, Climate and biomes in the West Mediterranean area during the Pliocene: Palaeogeography, Palaeoclimatology, Palaeoecology, v. 152, no. 1-2, p. 15-36. doi:10.1016/ S0031-0182(99)00031-0.

Fleming, S.J., 1970, Thermoluminescent dating: refinement of the quartz inclusion method: Archaeometry, v. 12, no. 2, p. 133-143. doi:10.1111/j.1475-4754.1970.tb00016.x.

Font, N., 1897, Catalech Espeleologich de Catalunya: Butlletí del Centre Excursionista de Catalunya, no. 24, p. 8-20; no. 25, p. 79-84; no. 26, 
p. 107-112; no. 27 , p. 141-149; no. 29 , p. 197-202; no. 31, p. 235-238; no. 32 , p. $249-253$; no. 33 , p. $266-274$; no. 35 , p. $311-323$.

Font, N., 1899, Sota Terra, Excursió espeleológica a la Baronia d'Aramprunyà, Conferencia llegida'l dia 30 de Desembre de 1898: Butlletí del Centre Excursionista de Catalunya, v. 9, no. 57-58, p. $233-252$.

Fouache, E., Ghilardi, M., Vouvalidis, K., Syrides, G., Styllas, M., Kunesch, S., and Stiros, S., 2008, Contribution on the Holocene reconstruction of Thessaloniki Coastal Plain, Greece: Journal of Coastal Research, v. 24, no. 5, p. 1161-1173. doi:10.2112/06-0786.1.

Ford, D.C., and Williams, P.W., 2007, Karst Hydrology and Geomorphology: Chichester, John Wiley and Sons Ltd, 562 p.

Freixes, A., 1989, El karst en las Cordilleras Costeras Catalanas, in Durán, J.J., and López-Martínez, J., eds., El karst en España, Sociedad Española de Geomorfologia, Monografia, v. 4, p. 145-149.

Furió, M., 2007, Los insectívoros (Soricomorpha, Erinaceomorpha, Mammalia) del Neógeno superior del Levante Ibérico [Ph. D. thesis]: Bellaterra, Universitat Autònoma de Barcelona, 299 p.

Gallart, F., 1980, Estudi geomorfològic del Penedès, sector Anoia i Riudebitlles [Ph. D. thesis]: Barcelona, Universitat de Barcelona, $247 \mathrm{p}$.

García-Alix, A., Minwer-Barakat, R., Martín-Suárez, E., and Freudenthal, M., 2007, New data on Mio-Pliocene Sciuridae (Rodentia, Mammalia) from southern Spain: Comptes Rendus Palevol, v. 6, p. 269-279. doi:10.1016/j.crpv.2007.02.001.

Gibbard, P.L., Bryant, I.D., and Hall, A.R., 1986, A Hoxian interglacial doline infilling at Slade Oak Lane, Denham, Buckinghamshire, England: Geological Magazine, v. 123, no. 1, p. 27-43. doi:10.1017/ S0016756800026510.

GIRES (Grup d'Investigacions i Recerques Espeleològiques Sesrovires), 1995, Avenc Gran de les Alzines, Pla d'Ardenya, Vallirana: Speleological Unpublished Report, Barcelona, Centre Excursionista de Vallirana, $16 \mathrm{p}$.

Guérin, C., 1980, Les Rhinoceros (Mammalia, Perissodactyla) au Pléistocène Superieur en Europe Occidentale; Comparasion avec les Espèces Actuelles: Documents des Laboratoires de Géologie de Lyon no. 79,1185 p.

Guillén, J., 2010, Canal Negre 1, jaciment càrstic de vertebrats del Miocè, Pliocè i Pleistocè de Catalunya: Exploracions, no. 19, p. 7-87.

Guimerà, A., 1988, Estudi estructural de l'enllaç entre la Serralada Ibèrica i la Serralada Costanera Catalana [Ph. D. thesis]: Barcelona, Universitat de Barcelona, $600 \mathrm{p}$.

Hempel, L., 1991, Forschungen zur physischen Geographie der Insel Kreta im Quartär. Ein Beitrag zur Geoökologie des Mittelmeerraumes: Göttingen, Vandenhoeck and Ruprecht, Abhandlungen der Akademie des Wissenschaften in Göttingen, no. 42, 171 p.

Hoffmann, D., Pike, A.W.G., Wainer, K., and Zilhão, J., 2013, New Useries results for the speleogenesis and the Palaeolithic archaeology of the Almonda karstic system (Torres Novas, Portugal): Quaternary International, v. 294, p. 168-182. doi:10.1016/j.quaint.2012.05.027.

Jennings, J.N., 1985, Karst Geomorphology: Oxford, Basil Blackwell, $293 \mathrm{p}$.

Jones, W.K., Culver, D.C., and Herman, J.S., eds., 2004, Epikarst. Proceedings of the Symposium Held October 1 through 4, 2003, Sheperdstown, West Virginia, USA: Charles Town, West Virginia, Karst Waters Institute, Special Publication 9, 160 p.

Klimchouk, A., 2000, The formation of epikarst and its role in vadose speleogenesis, in Klimchouk, A., Ford, D., Palmer, A.N., and Dreybrodt, W., eds., Speleogenesis. Evolution of Karst Aquifers: Huntsville, National Speleological Society, p. 91-99.

Krijgsman, W., Hilgen, F.J., Raffi, I., Sierro, F.J., and Wilson, D.S., 1999, Chronology, causes and progression of the Messinian salinity crisis: Nature, v. 400, no. 6745, p. 652-655. doi:10.1038/23231.

Llopis, N., 1941, Morfología y hidrología subterránea de la parte oriental del macizo cárstico de Garraf (Barcelona): Estudios Geográficos, v. 2, p. 413-466.

Llopis, N., 1943, Estudio tectomorfológico de la terminación meridional de la depresión Prelitoral catalana: Estudios Geográficos, v. 4, p. $31-111$.

Llopis, N., 1947, Contribución al Conocimiento de la Morfoestructura de los Catalánides: Barcelona, CSIC-Instituto Lucas Mallada, 372 p.

Lloret, J., 1979, Catálogo espeleológico del pla d'Ardenya, Tomo 1: Barcelona, by the author, $106 \mathrm{p}$.
Luzón, A., Pérez, A., Soriano, M.A., and Pocoví, A., 2008, Sedimentary record of Pleistocene paleodoline evolution in the Ebro basin (NE Spain): Sedimentary Geology, v. 205, no. 1-2, p. 1-13. doi:10.1016/ j.sedgeo.2008.01.004.

Macpherson, I., 1994, Revisión bioestratigráfica de los depósitos marinos del Mioceno medio en la cuenca del Penedès: Acta Geológica Hispánica, v. 29, no. 2-4, p. 123-132.

Marfà, R. de, 2009, Els lagomorfs (O. Lagomorpha, Cl. Mammalia) del Pliocè i el Pleistocè europeus [Ph. D. thesis]: Barcelona, Universitat de Barcelona, $206 \mathrm{p}$.

Marriner, N., and Morhange, C., 2007, Geoscience of ancient Mediterranean harbours: Earth-Science Reviews, v. 80, no. 3-4, p. 137-194. doi:10.1016/j.earscirev.2006.10.003.

Martínez-Navarro, B., 2010, Early pleistocene faunas of Eurasia and hominin dispersals, in Fleagle, J.G., Shea, J.J., Grine, F.E., Baden, A.L., and Leakey, R.E., eds., Out of Africa I: The First Hominin Colonization of Eurasia: Dordrecht, Springer, Vertebrate Paleobiology and Paleoanthropology Series, p. 207-224. doi:10.1007/978-90481-9036-2_13.

Martínez-Navarro, B., Llenas, M., and Agustí, J., 2002, Estudio de las brechas fosilíferas del Avenc Marcel, Pla del Marge del Moro (Vallirana-Begues, Baix Llobregat): unpublished archaeological report, Barcelona, Servei d'Arqueologia i Paleontologia, Departament de Cultura i Mitjans de Comunicació, Generalitat de Catalunya, 4 p.

Marzo, M., 1979, El Buntsandstein de los Catalánides: estratigrafía y procesos de sedimentación [Ph. D. thesis]: Barcelona, Universitat de Barcelona, $317 \mathrm{p}$.

Maucci, W., 1960, La speleogenesi nel Carso Triestino: Bollettino della Società Adriatica di Scienze Naturali in Trieste, v. 51, p. 233-254.

Minwer-Barakat, R., García-Alix, A., Martín-Suárez, E., and Freudenthal, M., 2004, Arvicolidae (Rodentia) from the Pliocene of Tollo de Chiclana (Granada, SE Spain): Geobios, v. 37, p. 619-629. doi:10.1016/j.geobios.2004.05.001.

Minwer-Barakat, R., García-Alix, A., Martín-Suárez, E., and Freudenthal, M., 2008, The latest Ruscinian and early Villanyian Arvicolinae from southern Spain re-examined: biostratigraphical implications: Journal of Vertebrate Paleontology, v. 28, no. 3, p. 841-850. doi:10.1671/0272-4634(2008)28[841:TLRAEV]2.0.CO;2.

Moncel, M.-H., 2003, L'exploitation de l'espace et la mobilité des groupes humains au travers des assemblages lithiques à la fin du Pléistocène moyen et au début du Pléistocène supérieur. La moyenne vallée du Rhone entre Drôme et Ardèche: Oxford, Archaeopress, BAR (British Archaeological Reports) International Series 1184, 179 p.

Moncel, M.-H., Moigne, A.-M., and Combier, J., 2005, Pre-Neandertal behaviour during isotopic stage 9 and the beginning of stage 8 . New data concerning fauna and lithics in the different occupation levels of Orgnac 3 (Ardèche, South-East France): occupation types: Journal of Archaeological Science, v. 32, no. 9, p. 1283-1301. doi:10.1016/ j.jas.2005.03.014.

Montoriol, J., 1950, El campo de dolinas del Plá de Campgrás (macizo del Garraf, Barcelona): Speleon, v. 1, no. 2, p. 23-39.

Montoriol, J., 1954, La hidrología kárstica del Pla de les Basses y sus relaciones con la de otras zonas del macizo del Garraf (Barcelona): Speleon, v. 5, no. 1-2, p. 55-104.

Montoriol, J., 1964, Estudio de las formas kársticas hipogeas desarrolladas en los bordes del polje de Begues (Macizo del Garraf, Barcelona): Speleon, v. 15 , no. $1-4$, p. $3-38$

Montoriol, J., 1966, Las surgencias de las Costas del Garraf (Barcelona), in Akten des Dritter Internationaller Kongress für Speläologie, vol. 5: Viena, Verband österreichischer Höhlenforscher, p. 43-49.

Montoriol, J., and Muntan, L., 1958, Sobre la evolución del Fondo de les Tarradelles (nota complementaria): Speleon, v. 9, no. 3-4, p. 61-74.

Montoriol, J., and Muntan, L., 1959, Resultados de nuevas investigaciones en el campo de dolinas del Plá del Campgrás (Macizo del Garraf, Barcelona): Speleon, v. 10, no. 3-4, p. 127-152.

Montoriol, J., and Muntan, L., 1961, Resultados de las nuevas investigaciones sobre el karst del pla de les Bases (Macizo del Garraf, Barcelona): Speleon, v. 12 , no. 1-2, p. 35-55.

Moreno, J.A., 2007, Bioestratigrafía del Aptiense del macizo del Garraf (NE de la Península Ibérica: Geogaceta, v. 41, p. 131-134.

Mosquera, M., Ollé, A., Pérez-González, A., Rodríguez, X.P., Vaquero, M., Vergès, J.M ${ }^{\mathrm{a}}$, and Carbonell, E., 2007, Valle de las Orquídeas: un yacimiento al aire libre del Pleistoceno superior en la sierra de 
Atapuerca (Burgos): Trabajos de Prehistoria, v. 64, no. 2, p. 143-155. doi:10.3989/tp.2007.v64.i2.113

Nambi, K.S.V., and Aitken, M.J., 1986, Annual dose conversion factors for TL and ESR dating: Archaeometry, v. 28, no. 2, p. 202-205. doi:10.1111/j.1475-4754.1986.tb00388.x.

Piccini, L., Drysdale, R., and Heijnis, H., 2003, Karst morphology and cave sediments as indicators of the uplift history in the Alpin Apuane (Tuscany, Italy): Quaternary International, v. 101-102, p. 219-227. doi:10.1016/S1040-6182(02)00104-0.

Pickford, M., and Morales, J., 1994, Biostratigraphy and palaeobiogeography of East Africa and the Iberian Peninsula: Palaeogeography, Palaeoclimatology, Palaeoecology, v. 112, p. 297-322. doi:10.1016/ 0031-0182(94)90078-7.

Porcel, E., 2008, Els avencs de les Alzines, dels Arqueòlegs, dels Llambrics, de l'Emili Sabaté i Petit Pasant: Cavernes, v. 27, p. 36-47.

Porta, J. de, and Civis, J., 1996, La sucesión bioestratigráfica del Mioceno marino en el Penedès y en el horst de Tarragona-Bonastre (Neógeno del Sistema Mediterráneo): Geogaceta, no. 19, p. 97-100.

Quilès, D., Rohr, V., Joly, K., Lhuillier, S., Ogereau, P., Martin, A., Baziles, F., and Vernet, J.L., 2002, Les feux préhistoriques holocènes en montagne sub-méditerranéene: premiers résultats sur les Causse Méjean (Lozère, France): Comptes Rendus Palevol, v. 1, no. 1, p. 59-65. doi:10.1016/S1631-0683(02)00010-6.

Ramos, J., Bernal, D., Domínguez-Bella, S., Calado, D., Ruiz, B., Gil, M.J., Clemente, I., Durán, J.J., Vijande, E., and Chamorro, S., 2008, The Benzú rockshelter: a middle Palaeolithic site on the North African coast: Quaternary Science Reviews, v. 27, no. 23-24, p. 2210-2218. doi:10.1016/j.quascirev.2008.08.030.

Rook, L., and Martínez-Navarro, B., 2010, Villafranchian: The long story of a Plio-Pleistocene European large mammal biochronologic unit: Quaternary International, v. 219, p. 134-144. doi:10.1016/j.quaint. 2010.01.007

Rosas, A., Martínez-Maza, C., Bastir, M., García-Tabernero, A., LaluezaFox, C., Huguet, R., Ortiz, J.E., Julià, R., Soler, V., de Torres, T., Martínez, E., Cañaveras, J.C., Sánchez-Moral, S., Cuezva, S., Lario, J., Santamaría, D., de la Rasilla, M., and Fortea, J., 2006, Paleobiology and comparative morphology of a late Neanderthal simple from El Sidrón, Asturias, Spain: Proceedings of the National Academy of Sciences of the United States of America, v. 103, no. 51, p. 19266-19271. doi:10.1073/pnas.0609662104.

Rosas, A., Pérez-González, A., Carbonell, E., van der Made, J., Sánchez, A., Laplana, C., Cuenca-Bescós, G., Parés, J.M., and Huguet, R., 2001, Le gisement pléistocène de la "Sima del Elefante" (Sierra de Atapuerca, Espagne): L'Anthropologie, v. 105, no. 2, p. 301-312. doi:10.1016/S0003-5521(01)80018-2.

Rubinat, F., 1981, Catàleg espeleològic del massís del Garraf. Unitat septentrional. Sector 10: Gours, no. 8, p. 45-78.

Rubinat, F., 2004, Catàleg Espeleològic del Massís de l'Ordal: Barcelona, Centre Excursionista Àliga, EspeleoSie Monogràfic, 118 p.

Salas, R., 1987, El Malm i el Cretaci inferior entre el massís del Garraf i la serra d'Espadà. [Ph. D. thesis]: Barcelona, Universitat de Barcelona, 345 p.

Sauro, U., Ferrarese, F., Francese, R., Miola, A., Mozzi, P., Rondo, G.Q., Trombino, L., and Valentini, G., 2009, Doline fills. Case study of the Faverghera plateau (Venetian Pre-Alps, Italy): Acta Carsologica, v. 38 , no. 1 , p. $51-63$.

Shackleton, N.J., Hall, M.A., and Pate, D., 1995, Pliocene stable isotope stratigraphy of site 846, in Pisias, N.G., Mayer, L.A., Janecek, T.R., Palmer-Julson, A., and van Andel, T.H., eds., Proceedings of the Ocean Drilling Program, Scientific Results, v. 138: College Station Texas (Ocean Drilling Program), p. 337-355. doi:10.2973/odp.proc.sr. 138.117.1995.

Siart, C., Hecht, S., Holzhauer, I., Altherr, R., Meyer, H.P., Schukraft, G., Eitel, B., Bubenzer, O., and Panagiotopoulos, D., 2010, Karst depressions as geoarchaeological archives: The palaeoenviromental reconstruction of Zominthos (Central Crete), based on geophysical prospection, sedimentological investigations and GIS: Quaternary International, v. 216, no. 1-2, p. 75-92. doi:10.1016/j.quaint.2009. 06.020 .

Solé, L.L., 1964, Geología de los alrededores de Barcelona, in: Publicacionesde la Dirección General de Enseñanza Media. Colección "la Nueva Geografía". Ministerio de Educación Nacional, Madrid, no. 379 , p. 67-72.

Suc, J.-P., and Cravatte, J., 1982, Etude palynologique du Pliocène de Catalogne (Nord-est de l'Espagne): Paléobiologie Continentale, v. 13, no. 1, p. 1-31.

Suc, J.-P., Diniz, F., Leroy, S., Poumot, C., Bertini, A., Dupont, L., Clet, M., Bessais, E., Zheng, Z., Fauquette, S., and Ferrier, J., 1995, Zanclean ( $\sim$ Brunssumian) to early Piacenzian ( $\sim$ early-middle Reuverian) climate from $4^{\circ}$ to $54^{\circ}$ north latitude (West Africa, West Europe and West Mediterranean areas): Mededelingen Rijks Geologische Dienst, v. 52, p. 43-56.

Ufrecht, W., 2008, Evaluating landscape development and karstification of the Central Schwäbische Alb (Southwest Germany) by fossil record of karst fillings: Zeitschrift für Geomorphologie, v. 52, no. 4, p. 417-436. doi:10.1127/0372-8854/2008/0052-0417.

Valdepeñas, P., 2012, L'Avenc Nou de les Alzines: EspeleoCat, v. 9, p. 34-36.

Van Andel, T.H., 1998, Paleosols, red sediments, and the Old Stone Age in Greece: Geoarchaeology, v. 13, no. 4, p. 361-390. doi:10.1002/ (SICI) 1520-6548(199804)13:4<361::AID-GEA2>3.0.CO;2-0.

Van der Made, J., 2005, La fauna del Pleistoceno europeo, in Carbonell, E., coord., Homínidos: Las Primeras Ocupaciones de los Continentes: Barcelona, Ariel, p. 394-432.

Van der Made, J., 2010, The rhinos from the Middle Pleistocene of Neumark-Nord (Saxony-Anhalt), in Mania, D., and Meller, H., eds., Ein interglaziales Ökosystem des mittelpaläolithischen Menschen: Halle (Saale), Landesmuseum für Vorgeschichte, Veröffentlichungen des Landesamtes für Denkmalpflege und Archäologie Sachsen-Anhalt no. $62,433-527$.

Van der Made, J., and Grube, R., 2010, The rhinoceroses from NeumarkNord and their nutrition, in Meller, H., ed., Elefantenreich - eine Fossilwelt in Europa: Halle (Saale), Landesmuseum für Vorgeschichte, Begleithefte zu Sonderausstellungen 2, p. 383-398.

Waltham, T., Bell, F.G., and Culshaw, M.G., 2005, Sinkholes and Subsidence: Karst and Cavernous Rocks in Engineering and Construction: Chichester, Springer Praxis Publishing Ltd, 382 p.

Weninger, B., and Jöris, O., 2008, ${ }^{14} \mathrm{C}$ age calibration curve for the last $60 \mathrm{ka}$ : the Greenland-Hulu U/Th timescale and its impact on understanding the Middle to Upper Paleolithic transition in Western Eurasia: Journal of Human Evolution, v. 55, no. 5, p. 772-781. doi:10.1016/j.jhevol.2008.08.017.

Weninger, B., Jöris, O., and Danzeglocke, U., 2008, CalPal-2007. Cologne Radiocarbon Calibration and Palaeoclimate Research Package: http:// www.calpal.de/ [accessed 10 February 2012].

Zambo, L., and Ford, D.C., 1997, Limestone dissolution processes in Beke doline Aggtelek National Park, Hungary: Earth Surface Processes and Landforms, v. 22, no. 6, p. 531-543. doi:10.1002/(SICI)1096-9837(199706) 22:6<531::AID-ESP711>3.0.CO;2-I.

Zhu, Xuewen, and Waltham, T., 2005, Tiankengs: definition and description: Cave and Karst Science, v. 32, no. 2-3, p. 75-80.

Zilhão, J., Maurício, J., and Souto, P., 1993, Jazidas arqueológicas do sistema cársico da nascente do Almonda: Nova Augusta, v. 7, p. $35-54$.

Zimmerman, D.W., 1971, Thermoluminescence dating using fine grains from pottery: Archaeometry, v. 13, no. 1, p. 29-52. doi:10.1111/ j.1475-4754.1971.tb00028.x 